\title{
Aspectos de la «Fortuna Privata»: Culto individual y doméstico. Popularización del culto como protección mágica
}

\author{
Aspects of the «Fortuna Privata»: Individual and domestic cult: \\ Cult as a magic protection.
}

\author{
Marta BaILÓn García*
}

\begin{abstract}
RESUMEN
ABSTRACT

Dentro de la gran diversidad de cultos que nos ofrece la diosa Fortuna, en el presente estudio pretendemos acercar dos de sus aspectos fundamentales: el culto individual visto como genio tutelar o numen y el culto doméstico que se le ofrecía a Fortuna como diosa de larario dentro de los hogares. Durante la crisis ideológica que sufre el Imperio romano durante los siglos II y III d.C. y ante la búsqueda de respuestas filosóficoreligiosas ante la vida y existencia, Fortuna se constituirá en una protección supersticiosa y mágica.

PALABRAS CLAVE: Fortuna Dea, Larario, Culto domestico, Protección mágica.

Inside of the big diversity of culs that show us the goddness Fortuna, in this study we want to see two things: the indivial cult or numen and the domestic cult offer to Fortuna like goddness of the lararii in the houses. During the ideological crisis that suffer the Roman empire between II and III centuries A.D. People looked for philosophical and religious answers about life, Fortuna was then a magic ans superstitious protection.

KEYWORDS:

Fortuna Dea, Larario, Cult domestic, Magic protection.
\end{abstract}

No hay divinidad que los romanos hayan adaptado mejor que Fortuna a todas las circunstancias de la vida del hombre, tanto dentro del ámbito privado como público, tocando a todos los individuos y colectivos sociales. El poder que Fortuna puede ejercer sobre el ser humano se puede presentar bajo dos aspectos fundamentales: como numen o genio tutelar y como diosa, tanto pública como privada. Esta gran diversidad que encontramos en la esencia de nuestra divinidad queda manifestada tanto en los datos iconográficos aportados por la arqueología como en

* UNED. Alegría de la huerta, 26, Madrid. titabailon@yahoo.es. 
las fuentes clásicas (que describen tanto a las representaciones figurativas como los atributos que posee Fortuna, tanto a nivel colectivo como a nivel individual). Fortuna recibe sus numerosas atribuciones de otras divinidades, sobre todo femeninas, asimilando sus funciones. También la encontramos asociada a otras muchas, en este caso más bien masculinas, multiplicando de esta forma la protección o influencia que realiza sobre distintos grupos sociales (en cambios sociales y políticos a nivel de Estado) como individuales. En el siguiente estudio también pretendemos recoger las conexiones o sincretismos iconográficos de la diosa tanto con el panteón romano como con las divinidades indígenas, utilizando como ejemplo el caso de la provincia hispana'.

Podemos destacar que el mayor auge del culto a Fortuna suele coincidir con épocas de crisis de pensamiento y búsqueda de nuevos elementos intelectuales y culturales. Así la abstracción, el genio o diosa que rige los destinos de dioses y hombres se vuelve un elemento fundamental para lograr el éxito o fracaso de la vida humana en tiempos donde gobierna la incertidumbre y donde los viejos valores se hallan en franca decadencia. Aunque la presencia de la diosa Fortuna siempre estuvo presente a lo largo de la historia de Roma, desde sus orígenes monárquicos, cabe destacar que es en época del Imperio, concretamente durante los siglos II y III d.C., donde mayor fuerza adquiere su advocación, popularizándose su culto tanto en el contexto individual y como en el público, adquiriendo un componente de protección mágica que perdurará a lo largo de la historia alcanzando la Edad Moderna ${ }^{2}$.

En este estudio pretendemos analizar la Fortuna que representa la condición privada de cada hombre, es decir, la «Fortuna Privata» en sus dos aspectos; individual y doméstico.

Por un lado nos encontramos ante una Fortuna individual que pertenece a cada hombre. El culto a la diosa queda constituido como un acto privado e individual. Los beneficios que otorga la diosa son de carácter particular. Esta Fortuna se concibe como numen, genio tutelar o fuerza que nace con cada hombre; le guía a lo largo de su vida y finalmente muere con él. Cada individuo nace con una «fortuna», y nadie puede tener la «fortuna» de otro. Ésta es una fuerza móvil e ines-

1 Podemos ver aspectos generales de la diosa Fortuna en: Daremberg, Ch; Saglio, EDM; Dictionnaire des antiquités Grecques et Romaines; Graz, Austria, 1963. Grimal, P; Diccionario de mitología griega y romana; Barcelona, 1981. Champeaux, J; Fortuna. Le culte de la Fortune dans le monde romain. II Les transformations de Fortuna sous la République; Roma, 1987. Id; Fortuna: Recherches sur le culte de la Fortune à Rome et dans le monde romain des origins à la mort de César. I Fortuna dans la religión archaïque; Roma, 1982. Allègre, F.; Étude sur la déesse grecque Tyché. Sa signification religieuse et morale, son culte et ses représentations figurées; París, 1889. Galinsky, K.(Dir.); The goddes Fortuna in Imperial Rome: Cult, Art, Text, Texas, 2002. Montero Herrero, S., Perea Yébenes, S.; «llu revista de Ciencias de las religiones. Roma Religio/Religio Romanorum. Diccionario Bibliográfico de Religión Romana; Madrid, 1999. Seco Serra, l; Señora del Destino. La diosa Isis en el mundo greco-romano; Revista de Arqueología N.²1 (233). 2000, pp. 42-49.

2 Sobre los orígenes y transformaciones sociales y culturales destacamos: Fernández Uriel, P; Historia de Roma. V. II; Madrid, 2001. Vázquez Hoys, A. M.; Praeneste y la Fortuna Primigenia. Magia y religión en un culto sincrético; AKROS. Melilla, 2005, pp. 43-48. Turcan, R.; Los cultos orientales en el mundo romano; Madrid, 2001. 
table que se mueve elevando o hundiendo a los hombres caprichosamente. Se concibe con el valor de «buena» 0 «mala» fortuna, fuerza propicia y favorable al individuo, o fuerza que persigue y maltrata causando el infortunio del individuo ${ }^{3}$.

La Fortuna romana que aparece como numen, es el resultado de la concepción abstracta de la Casualidad o Providencia divinizada en forma de diosa que rige los destinos de la humanidad, a la cual el hombre se halla sometido y cuya ayuda necesita tanto a nivel individual como a nivel colectivo (grupo social, ciudad, estado) para llevar a buen término todas las acciones emprendidas. Este espíritu guardián, personificación de la influencia caprichosa y móvil, también se localiza sobre acontecimientos o días concretos. La personificación de la influencia caprichosa y móvil, puede ser a veces nefasta, pero la mayoría de las veces suele ser favorable ${ }^{4}$.

Fortuna, en un principio, dentro de su componente particular, se constituye no sólo como divinidad individual sino también como protectora de todos los elementos sociales, sin hacer distinción entre grupos más o menos poderosos. De hecho los grupos o collegia más humildes de la población -mujeres, plebeyos, libertos, esclavos- serán los mayores defensores de esta deidad. En un principio el mundo ligado a la diosa Fortuna era algo relacionado con lo fortuito, con la magia, mundo característico de la mujer y por lo tanto visto con cierto rechazo por los sectores importantes del Estado. Esta peculiar visión, que relacionaba a Fortuna con los procesos mágicos, necesitaba ser depurada para que el Estado no se viera amenazada de posibles peligros.

Cuando la diosa sufre estas transformaciones bajo la advocación de Fortuna Publica populi Romani Quiritium es donde el culto de la diosa pasa de un carácter particular o privado a uno más genérico y colectivo, constituyéndose en culto oficial de Fortuna. Este culto oficial tendrá su reflejo en la gran estatuaria, o en la diferente producción monetal, con la inserción de nuestra diosa en el culto imperial ${ }^{5}$.

Fortuna Dea poseía diferentes advocaciones, cultos o festividades, debido a sus amplias atribuciones y a la multitud de sectores sociales a los que afectaba. Podemos citar algunos de los numerosos calificativos que recibía: «Adiutrix, $A e-$

${ }^{3}$ Apuleyo, en sus Metamorfosis (Libro VIII 20), mediante una invocación nos muestra una de las naturalezas de Fortuna como Genio Tutelar; «Por la Fortuna, por el Genio [divinidad protectora de cada hombre] de cada uno de vosotros, socorred a este anciano en su abandono (...)»; Rodríguez Alonso, C; Tyche y Areté en el proceso histórico de Roma según Plutarco; García Valdés, M. (Ed.); Estudios sobre Plutarco: ideas religiosas. Actas del III simposio internacional sobre Plutarco, Oviedo 30 abril a 2 mayo de 1992; Ed. Clásicas. Madrid, 1994, pp. 447-448.

4 Grimal, P; Op.Cit. Daremberg, Saglio; Op.Cit. Montero Herrero, S; Diosas y adivinas. Mujer y adivinación en la Roma antigua; Madrid, 1994, p. 29. Cumont, Franz; Las religiones orientales y el paganismo romano; Madrid, 1987. (Conferencias pronunciadas en 1905), pp. 47-48.

5 No corresponde en este trabajo hacer el estudio sobre la Fortuna Pública pero para más información sobre este tema ver: Étienne, R.; Étienne, R.; Le culte imperial dans la Péninsule Ibérique d'Auguste á Dioclétien; París, 1974. Champeaux, J; Fortuna II.. Fernández Uriel, P; Historia de Roma. V. II; Madrid, 2001; Elvira Barba, M.A.; Schröder, S.; Bajo el signo de Fortuna. esculturas clásicas del Museo del Prado; Salamanca, 1999; Lichocka, B.; L'lconographie de Fortuna dans l'Empire Romain (Ier siècle avant N.È.-IVe siècle de N.È.); Pologne, 1997. 
terna, Alma, Antiates, Arelatensis, Augusta, Balnearis, Barbata, Beata, Bona, Breuis, Cancesis (o Camcesis), Casualis, Citerioris, Caelestis, Colenda, Conseruatrix, Crassiana, Diua, Domestica, Dubia, Dux, Ephesia, Equestris, Felix, Filia Iouis, Flauia, Folianensis, Inuictrix, Iuveniana, Magna, Mala, Mammosa, Manens, Melior, Memor, Muliebris, Nemausensis, Nemesis, Obsequens, Opifera, Panthea, Pientiana, Praenestina, Praesens, Praetoria, Primigenia, Privata, Publica, Redux, Respiciens, Restitutrix, Salutaris, Sancta, Servatrix, Stabilis, Supera, Torquatiana, Tulliana, Tutatrix, Tutela, Victrix, Virgo, Viriles, Viruniensis, Viscata».

Además de estos, Fortuna Dea, como protectora de objetos, lugares, ciudades, hombres, emperadores puede aparecer ligada a personas o lugares concretos como son los casos de Fortuna Augusti o Augustorum (CIL III 1421, CIL VI 180), F. Huius Loci (CIL III 10399; VI, 177), F. Imperii (CIL XI 3075), F. Legionis (XIL III 10992), F. Municipii (CIL IX 2586), F. Populi Romani (CIL VII 702)6.

Por la naturaleza de la diosa, Fortuna tiene una vinculación importante con los distintos grupos o collegia femeninos. Hay numerosas advocaciones o cultos de la diosa que quedan ligados a las diferentes escalas sociales en las que se encuentre la mujer.

El caso de la advocación de Fortuna Primigenia, seguida fundamentalmente por mujeres y ligada al conjunto sagrado de Praeneste, se remonta a la época monárquica de Servio Tulio, y tiene un carácter oracular. La mujer desde la más remota antigüedad ha quedado especialmente ligada al mundo mágico por su predisposición psicológica especial, excluyendo de este ámbito al hombre. De esta forma este aspecto religioso poco conocido en la vida pública era repudiado e incluso perseguido. En esta advocación era considerada como una diosa-madre cuya protección se extendía a las parturientas y a las matronas. El carácter oracular del templo de Praeneste se hacía por medio de la extracción de sors, o de tablillas que señalaban la suerte o destino de la solicitante.

El culto de la advocación de Fortuna Virgo o Virginalis era seguido por las novias romanas, antes del matrimonio. Las cuales dedicaban a la diosa juguetes y ropas de la niñez, antes del gran cambio vital, tras el matrimonio, que las llevaría a la edad adulta.

El aspecto masculino de este culto lo tenemos en la Fortuna Barbata que protegía al joven en el paso de la pubertad a la virilidad o mayoría de edad ${ }^{7}$.

6 Para las advocaciones de Fortuna podemos ver: Kajanto, I.; Fortuna; ANRW, II. 17.1., 1981, pp. 510-516; González Fernández, R.; La diosa Fortuna. Relaciones con las aguas y los militares. El caso particular del Balneario de Fortuna (Murcia); en La cultura latina en la Cueva Negra. En agradecimiento a los Profs. A.Stylow, M.Mayer e I.Velázquez; Antig. Crist. XX. Murcia, 2003, pp. 374.

7 Montero Herrero, S; Diosas y adivinas..., pp. 29-30. Pomeroy, S.; Diosas, rameras, esposas y esclavas. Mujeres en la Antigüedad clásica; Madrid, 1987, p. 230. Champeaux, J; Fortuna I. Id.; Fortuna II. Id.; Sors Oraculi: les oracles en Italia sous la République et l'Empire; MEFRA 102, 1990.Vázquez Hoys, A.M.; Praeneste...

En el presente trabajo no corresponde analizar otros cultos ligados al mundo femenino por considerarlos de carácter público. Este es el caso de la advocación de Fortuna Muliebris, seguida por las ma- 
Un ejemplo al respecto lo encontramos en el Estandarte de Pollentia (Mallorca), actualmente en el Museo Arqueológico de Madrid, perteneciente a un collegium iuvenum, es decir, al colectivo de jóvenes que iban a formar parte del ejército. Este estandarte tiene un carácter cívico-religioso. Insertas en él se encuentran representaciones de diferentes divinidades, entre las cuales podemos destacar en un nivel superior la del Genio del joven (el cual es reconocible porque lleva la bulla colgada del cuello. Esta pequeña bolsa se utilizaba para guardar la primera barba), acompañado en un nivel inferior de las divinidades de Isis-Fortuna y Fortuna. La protección de estas divinidades va destinada a esos jóvenes que forman parte del ejército. Por lo tanto Fortuna queda en este caso ligada a la protección tanto del joven, que acaba de efectuar su paso vital de la niñez a la virilidad, como del estamento del ejército ${ }^{8}$.

Fortuna Dea, bajo diferentes advocaciones, también extendió su protección sobre los hombres. Dentro de los colectivos profesionales o collegia, el que más veneró a esta deidad fue el ejército. El culto y seguimiento de la diosa Fortuna supone la protección ante cualquier adversidad, ya que la misma es dueña del Destino y puede llevar a buen término cualquier acción militar o de otra índole. Así pues, esta gran participación en el culto a Fortuna por parte del ejército, tiene sobre todo un componente psicológico. La participación de la milicia dentro de los diferentes cultos a Fortuna Dea podía ser realizada tanto a título individual como colectivo. La epigrafía nos muestra que estos cultos tuvieron más importancia en las provincias limítrofes del Imperio, tales como Germania, Britania, Panonia y Dacia. Estas zonas eran las más expuestas al peligro exterior y donde la población militar era más importante.

Era importante la advocación de Fortuna Balnearis que se refiere a la higiene, aseo personal y recreo del soldado. Sólo mantiene una relación con métodos curativos o de la salud en cuanto a que esta higiene personal cure alguna enfermedad del soldado. Otro culto relacionado con el ejército es el de Fortuna Salutaris, que en ocasiones se relaciona con el anterior. Este último tiene una función sanadora, protectora de la salud y el bienestar físico. La representación de Fortuna Sa-

tronas romanas en un culto formal. Sólo una univira, o mujer casada una sola vez, podía acceder a cultos matronales como este. Esta advocación extiende su protección sobre todos los aspectos de la mujer casada. Este culto era bien acogido por la mujer patricia, y de ello da buena cuenta las representaciones numismáticas de diferentes emperatrices dedicantes, como es el caso de Faustina la Menor.

Tampoco debemos incluir el culto a Fortuna Virilis, relacionado en numerosas ocasiones con el culto de Fortuna Balnearis (éste de ámbito masculino), por su asociación con las aguas y su poder benéfi$c o$, ya que se utilizaba para su fiesta los baños masculinos. En estos ritos las mujeres patricias no participaban, siendo sus dedicantes probablemente cortesanas y prostitutas, aunque pudiera ampliarse a mujeres plebeyas.

En origen, la Fortuna Virilis tendría las mismas funciones o complementaría a la Fortuna Barbata. Es decir, sería una advocación masculina, protectora del paso de la juventud a la madurez del hombre, y quedaría ligada al culto individual o doméstico.

8 Arce, J.; El significado religioso del estandarte romano de Pollentia (Mallorca); en La Religión romana en Hispania, Symposio organizado por el Instituto de Arqueología «Rodrigo Caro» del C.S.I.C., 1719 de diciembre de 1979, Madrid 1981, p. 75-95; Veny, C.; El estandarte romano de «Pollentia» testimonio de la existencia de un «collegium iuvenum»; en Mayurqa, Rev. Departament de Ciències Històriques i Teoria de les Arts. N. ${ }^{\circ}$ 29. Mallorca, 2003, pp. 51-70. 
lutaris suele ir acompañada de la representación de dioses de la medicina como Esculapio?.

Por otro lado, dentro de su carácter privado, hemos de destacar el culto a Fors Fortuna, seguido mayoritariamente por mujeres, esclavos y sectores pasivos e irrelevantes de la sociedad romana. Además de estos fieles también participaban en este culto ciertos colectivos profesionales, libertos o plebeyos. Este culto era rechazado por la nobilitas o grupos sociales más prestigiosos, debido a su relación con la adivinación natural o extracción de sors, vinculada a la Fortuna Primigenia anteriormente analizada. La adivinación natural estaba mal vista e incluso perseguida por la sociedad romana, mas era muy practicada por los grupos marginados socialmente como los esclavos. La extracción de sortes por parte de este grupo social era altamente solicitada e incluso practicada en ambientes domésticos ${ }^{10}$.

Además del genio de cada hombre o de los aspectos anteriormente analizados, la Fortuna Privata guarda relación con a los cultos domésticos, donde se la venera como a una diosa de larario dentro de los hogares. Los dioses Lares, de origen latino, etrusco y sabino, tenían la finalidad de proteger además del ámbito doméstico, las encrucijadas o las murallas ${ }^{11}$. El culto a los Lares, dioses protecto-

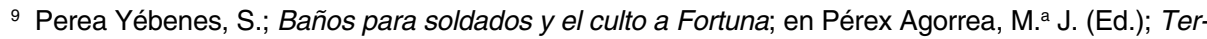
malismo Antiguo (I Congreso Peninsular. Actas); Madrid, 1997, pp. 159-167; González Fernández, R.; Op. Cit., pp. 378-381; Andrés Hurtado, G.; Una aproximación a la religión del ejército romano imperial: Hispania; Logroño, 2005.

Aspectos generales sobre la estructura y funcionamiento del ejército dentro del Imperio: Cabrero, J.; Breve síntesis bibliográfica sobre el ejército romano; ETF(2), 16, (2003), pp. 233-278; Le Roux, P.: L'armée romaine et l'organisation des provinces ibériques d'Auguste à l'invasion de 409; París, 1982; Id. (en prensa): Soldados hispanos en el ejército imperial romano; en Andreu, J., Cabrero, J., y Rodà, I. (eds): Hispania. Provincia Romana; Tarragona, s. Pp; Palao, J. J.; Legio VII Gemina (Pia) Felix: estudio de una legión romana, Salamanca, 2006; Roldán, J.M.; Hispania y el ejército romano. Contribución a la historia social de la España antigua; Salamanca, 1974.

En esta ocasión tampoco debemos considerar el culto de Fortuna Redux, o del feliz regreso, como un culto privado, ya que lo institucionaliza el emperador Augusto a su vuelta a Roma tras su viaje por Oriente. Fortuna en esta advocación se convierte en la diosa protectora del emperador durante sus viajes y expediciones. De esta forma Fortuna Redux forma parte del ceremonial oficial de los viajes imperiales, dentro de un culto público. Hay numerosas piezas monetales que atestiguan la importancia de este culto para los principados de las Dinastías Flavia (bajo Vespasiano y Domiciano) y Antoniniana (Trajano), principado de Marco Aurelio, de la Dinastía Severa (bajo Septimio Severo) y principado de Aureliano.

10 Montero Herrero, S.; Adivinación y esclavitud en la Roma antigua; «llu revista de Ciencias de las religiones; Madrid, 1995, pp. 151-152; Id.; Diosas y adivinas, p. 30. Digesto Libro XI, 5. Dentro del mismo se prohiben los juegos de azar, se ilegalizan los dados, que de alguna manera entronca con la extracción de sors o sortes. Cicerón (De Div, II, 41) nos muestra la opinión negativa que ofrece el orden senatorial y patricio respecto a los juegos de azar (morra, tejos o dados) por ser el resultado de la suerte o casualidad y no participar en ellos la razón.

11 Estudios sobre culto doméstico: Fernández Uriel, P.; Espinosa, T.; Lararios y culto privado. A/gunos aspectos; en Actas de Congreso Internacional El mundo religioso hispano bajo el Imperio romano. Pervivencias y cambios; Valladolid, 19-21 Octubre 2006. Orr, D. G.; Roman domestic religion: The evidence of the household shrines; ANRW II. 1978, pp. 1557-1591. Rodríguez Oliva, P.: Materiales arqueológicos y epigráficos para el estudio de los cultos domésticos en la España romana; Actas VIII Congreso Español de Estudios Clásicos. Vol. III. Madrid, 1994, pp. 5-40. Rodríguez García, P.; Cultos domésticos en la Galicia Romana; Congreso de Arqueología Peninsular. Acta de Congreso; Universidad de Alcalá de Henares, Zamora, 1999, pp.147-151. Calvo Martín, M. ${ }^{a}$ J.; Dioses de los caminos en el mundo antiguo; Rev. Arqueología. N. ${ }^{\circ} 220$, pp. 20-30, p. 7. Lozano, A.; Antropónimos griegos en la epigrafía religiosa la- 
res del hogar y de los antepasados, entre los que podemos encontrar divinidades asociadas como Fortuna, era transmitido por los antepasados, siendo propios tanto de los grupos sociales dirigentes como de los grupos minoritarios (ejército, comerciantes, sectores liberales, siervos o esclavos). Según Cicerón, Leg. II 11.; "conservar los ritos de la familia y de los padres es como conservar una religión transmitida por los dioses, porque la antigüedad se aproxima mucho a los dioses". En épocas anteriores al Imperio se utilizaban términos como Sacrarium, Sacellum o Aedicula para designar los pequeños recintos donde se depositaban las pequeñas representaciones de los dioses Lares. Es a partir de época imperial cuando se desarrolla el Lararium, con algunas modificaciones. Los recintos se amplían. Así mismo, las imágenes domésticas, en un principio de madera, se sustituyen por otros materiales como la piedra, la cerámica o el metal, son abundantes los ejemplos iconográficos elaborados en bronce.

Para el culto a los dioses Lares podemos distinguir dos grandes etapas. En la primera, que abarcaría hasta la llegada del Imperio, los dioses domésticos conservan su carácter original de protección de la familia y la casa. En la segunda etapa se amplían las dependencias propias que acogen a los dioses del hogar, incluyéndose en las mismas estancias a otras divinidades protectoras procedentes de la restauración de los diferentes cultos. Es en esta época cuando la diosa Fortuna entraría a formar parte del culto domestico en los diferentes Lararia, ejerciendo su protección sobre el ámbito familiar ${ }^{12}$.

Tenemos numerosos ejemplos de representaciones o estatuillas realizadas en diferentes materiales, como cerámica, terracota, bronce o pintura. La finalidad posible de estas representaciones (Fig. 01-08) es formar parte de un larario, aunque también podemos apuntar la posibilidad de que formen parte de una serie de exvotos o representaciones de la diosa ofrecidas como agradecimiento o petición de protección, como a continuación veremos ${ }^{13}$.

tina. Contribución al estudio sociológico de la religión romana en Hispania; Gerión 7. Madrid, 1989, pp. 19-20.

Ovidio en sus Metamorfosis muestra el origen de los gemelos dioses Lares haciendolos descendientes de Mercurio y la ninfa Lara. Se les representa como dos adolescentes cuyo atributo fundamental es el cuerno de la abundancia, vestidos con una túnica corta y apoyados en un pie.

${ }_{12}$ Al final de la República, Roma se hallaba ante una gran crisis de pensamiento religioso. Augusto fue el gran artífice de la mayor restauración de diferentes cultos perdidos o devaluados, al mismo tiempo que instauró el culto imperial.

Así la novela de Petroneo (El Satiricón 29) nos muestra, de forma irónica, como la diosa Fortuna suele formar parte habitual de los lararios de los hogares.

Noguera Celdrán, J.M., Navarro Suarez, F.J.; La «Fortuna» del Museo Arqueológico de Murcia: Notas para el estudio de este tipo de estatuillas; en Arce, J., Burkhaltes, F.; Bronces y religión romana; Actas del XI Concreso Internacional de Bronces Antiguos; Madrid, 1993, pp. 327-328.

Como ejemplo de la popularización del culto a los dioses Lares podríamos destacar el caso de la provincia de Hispania, efectuado por medio de distintos sincretismos con varias divinidades indígenas con atributos similares a los Lares, en Blázquez Martínez, J.M. a; Diccionario de las Religiones Prerromanas de Hispania; Madrid, 1975, pp. 113 y ss.

${ }_{13}$ Catálogo de Lararios o dependencias para los dioses Lares: Boyce, G.K.; Corpus of the Lararia of Pompeii; MAAR, XIV. 1937.; Maiuri, A.; La casa a Pompei; Corso Universitari di antichità Pompeiane dell'anno 1950-51; Nápoli, 1951; Dwyer, E.J.; Pompeian Domestic Sculture. A study of five pompeian Hauses and their contexts; Roma, 1982. 
Mediante un estudio iconográfico podemos percibir que Fortuna constituyó una divinidad tremendamente popular, mediante la proliferación no sólo de numerosos cultos sino también de sus numerosas atribuciones, éstas visibles en las diferentes representaciones, de las cuales ponemos algunos ejemplos a lo largo de nuestro estudio. Cada objeto que acompaña a la diosa constituye un atributo o poder que Fortuna ejerce sobre la humanidad, ya sea protegiéndola, ya sea sometiéndola a su voluntad. Los atributos principales de la Fortuna romana, con los que suele ir acompañada aunque en ocasiones carece de alguno de ellos en sus representaciones, son el gorro sacral, modius o celemín signo de la abundancia, el cuerno de Amaltea o de la abundancia, el timón o rueda que dirige el rumbo de la vida y los acontecimientos humanos ${ }^{14}$.

El Cuerno de la Abundancia Fortuna lo comparte con divinidades como Abundancia, Annona o Concordia. Es símbolo de prosperidad, y está compuesto por numerosos frutos y cereales, y su presencia se remonta a la mitología más antigua. Según la tradición Zeus (Júpiter) fue amamantado por una cabra llamada Axis o Amaltea durante su estancia en Creta, a la cual un día, entre juegos, rompió uno de sus cuernos. Recomponiéndolo se lo volvió a ofrecer otra vez a su nodriza cargado con un nuevo don; de él se podía comer y beber eternamente (néctar y ambrosía, alimento de los dioses) pues éste nunca dejaría de proporcionar alimentos en abundancia, además de toda clase de frutas. La representación de frutos como uvas o granadas, símbolos de fertilidad o fecundidad, saliendo del Cuerno ligan a las divinidades que lo portan con la tierra, el agua y los ciclos femeninos. Hay ocasiones en que a la diosa le acompaña un doble cuerno, bifurcándose el cuerpo central en dos aberturas, aportando mayores frutos y por tanto mayores beneficios (Fig. 05, 09, 12).

Otro de los atributos más destacados en las representaciones de Fortuna es que su mano derecha suele sujetar un timón de embarcación. El timón, la proa de barco o la rueda, los tres atributos con la misma simbología, son de origen romano. Mediante este atributo la diosa rige o gobierna los destinos humanos, divinos y naturales, así como la dirección de los Estados o el destino de la historia. Y este timón lo maneja según su voluntad. Además de protectora del Destino, y mediante este atributo, se convierte en diosa del mar y sus navegantes. La rueda como símbolo del movimiento perpetuo e inestable o símbolo de viaje será compartido con otras divinidades como Némesis, Júpiter, Mercurio, Felicitas, Hércules, Cibeles, Esculapio, Isis, Diana y Ceres.

Estudios sobre objetos y estatuillas de bronce encontramos en: Arce, J.(Coord); Los Bronces Romanos en España; Madrid, 1990; Thouvenot, R.; Catalogue des figurines et objets de Bronze au Musée archéologique de Madrid. I. Bronzes greecs et romains; Bheh, Fasc. XII, 1. Bourdeauz, París, 1927; Paris, P; Le Musée archéologique National de Madrid; Paris, 1936; Abascal Palazón, J.M.; Sanz Gamo, R.; Bronces antiguos del Museo de Albacete; Albacete, 1993.

14 Sobre la representación de los diferentes atributos de Fortuna podemos ver: Grimal, P.; Op. Cit. Elvira Barba, M.A.; Schröder, S.; Bajo el signo de Fortuna. esculturas clásicas del Museo del Prado; Salamanca, 1999. García y Bellido, A.; Esculturas romanas de España y Portugal; Madrid, 1949. Lichocka, B.; Op. Cit.; Turcan, R.; Iconography of religions. Section XVII, 1. Religion romaine. Part 1, 2; The Netherlands, 1988. Del Cerro Calderón, G.; Reflexiones sobre la diosa Tykhe / Fortuna; Analecta Malacitana; 27. N. ${ }^{\circ}$; Málaga, 2004, pp. 143-154. Seco Serra, I; Op. Cit. 
Bajo el timón suele representarse un pequeño globo, que simboliza la influencia de la diosa en todo el Universo, dentro de la vida personal y pública donde se podía esperar fortuna, y su influencia cósmica. Algunas veces Fortuna lleva el globo en una mano. El globo también es un elemento corriente en la iconografía del emperador, en su mano o bajo su pie, siempre es un signo de dominación del mun$\mathrm{do}^{15}$.

El modius o gorro sacral suele ir acompañado junto a una diadema puesta en primer lugar. El modius era un recipiente que se utilizaba como medida para cuantificar los cereales. Esta alta tiara algunas veces va ricamente decorada con símbolos que representan estrellas, como signo de poder cósmico o telúrico. El modius, al igual que el Cuerno de la Abundancia, debe ponerse en relación con la protección de la diosa sobre los ciclos tanto femeninos como agrícolas, en cuanto a símbolo de fecundidad, riqueza y abundancia. Un ejemplo muy claro lo tenemos en las Fig. 07, 16 aunque también podemos distinguir este atributo en las Figuras 01, 02 (estos en forma de estrella) y 03. Las Fig. 04, 05, 10 y 18 llevan todas sobre su cabeza una estilizada diadema que se convierte en un gorro sacral. Podemos destacar que aunque las figuras tienen distinta procedencia, los modelos y atributos se representan de igual forma a lo largo del Imperio, ya sean representaciones elaboradas en talleres locales o en grandes talleres para su posterior exportación.

La diadema junto con el modius puede sufrir una pequeña evolución convirtiéndose en una diadema poliada. Al mismo tiempo la diosa cambiará sus atribuciones y su protección, que esta vez ira dirigida a la salvaguarda de las ciudades o recintos amurallados. La representación de estas diademas poliadas representan los muros que acompañarían los límites de la ciudad y que las protegerían de ataques exteriores. A estas representaciones se las conoce como Fortuna Tutela. Encontramos un buen ejemplo de esta advocación protectora en la Fig. 09. Esta diadema poliada Fortuna la comparte con otras diosas como Rea, Cibeles y Deméter. A la Tyché de las ciudades, vulgarizada en Oriente por la influencia romana, tiene su correspondencia en Occidente, en particular en el caso de Hispania con la advocación de Tutela que da su nombre a gran cantidad de localidades —bajo la forma de Tudela- ${ }^{16}$.

Sumamente importante es el sincretismo de Fortuna con Isis, la cual, después de introducirse los cultos mistéricos en el Imperio, llega a fundirse con Fortuna con-

15 Lichocka, B.; Op. Cit., pp. 36-38. Además de los testimonios arqueológicos tenemos testimonios escritos que nos describen la iconografía y atribuciones de la diosa Fortuna. Podemos destacar a Dión de Prusa (Discursos. Sobre la Fortuna I. L. XIII, 7); «Pues unos la colocaron sobre una navaja de afeitar, otros sobre una pelota, otros le dieron un timón para que lo sujetara (...)La navaja de afeitar significa lo repentinamente que cambia la buena suerte; la pelota, la facilidad con que cambia, pues se da la circunstancia de que lo divino está siempre en movimiento. El timón demuestra que la Fortuna dirige la vida de los hombres (...)No llamemos, pues, mala a ninguna Fortuna, lo mismo que tampoco llamaría nadie a la Virtud, ni a lo bueno malo».

${ }_{16}$ Daremberg, Saglio; Dictionnaire, p. 1276. Respecto a las diferentes representaciones Fortuna-Tutela (protectora de ciudades) y sincretismos de Fortuna con otras Abstracciones divinizadas: Grimal, P.; Op. Cit. Champeaux, J.; Fortuna II. Lichocka, B.; Op. Cit. Étienne, R.; Op.Cit. Perea Yébenes, S.; Op. Cit. Beltrán Llois, M. (dir.); Caesaraugusta. Las aguas sagradas del Municipium Turiaso. Excavaciones en el patio del colegio Joaquín Costa (Antiguo Allué Salvador). Tarazona. Zaragoza; Zaragoza, 2004. 
virtiéndose en Isis-Fortuna. Este sincretismo se convierte en el más popular, entre las divinidades, sobre todo a partir del siglo II d.C., y así se traduce a la hora de comprobar la proliferación de figurillas de Isis-Fortuna dentro de los lararios. De los numerosas representaciones que podemos encontrar hemos recogido algunos ejemplos (Figuras $03,04{ }^{17}, 05,06,07,13$ y 15.). Los caracteres de ambas divinidades son compatibles, ya que Fortuna desde su origen latino tiene un fuerte carácter oracular como cualidad principal e Isis es la Señora de la Magia. Además de esta propiedad Isis-Fortuna se constituirá como Señora protectora de los navegantes y Dueña del Destino. La protección de la navegación resulta del viaje realizado por Isis en busca del cuerpo de su esposo-hermano Osiris esparcido por el mar por su hermano Seth y del poder otorgado a Fortuna para controlar todos los movimientos y acontecimientos naturales y humanos ${ }^{18}$.

Dentro de los numerosos atributos que Isis lega a Fortuna podemos destacar el vestido de Isis (queda visible en la Fig. 04) completado con un chal de flecos anudado de manera especial (mediante el llamado nodus isiacus). El tocado mediante el que se suele reconocer a este sincretismo puede diferir, representándose flores de loto, discos lunares, serpientes egipciantes, plumas, flores...

La representación de serpientes (podemos señalar el brazalete que lleva en su muñeca derecha la Fig. 04) suelen estar presentes. La serpiente es un animal regio, con carácter ctónico, apotropaico, espíritu de ancestros, emblema de fecundidad, símbolo de resurrección y vida, guardián de templos y personas ${ }^{19}$.

El atributo que se identifica con Isis en la pequeña representación de la Fig. 07 es la media luna que se superpone a los frutos del Cuerno de la Abundancia y el Sistro que lleva en su mano derecha. El Sistro es el instrumento musical sagrado y mágico que utiliza Isis y sus dedicantes. Es un instrumento musical de metal en forma de aro o de herradura, atravesado por varillas que se hace sonar agitándolo con las manos.

17 Esta representación resulta más compleja. Además de tener los atributos tanto de Fortuna como de Isis, a estas dos se le suma la protección y los poderes de Minerva, a través de la representación de la armadura y la égira (especie de peto o coraza adornado con la cabeza de la Gorgona o Medusa). En este caso Fortuna más que tomar las características guerreras de Minerva, transforma las mismas hasta convertirse en diosa protectora de las ciudades ante ataques externos, además de proteger los oficios dentro de los mismos muros de la ciudad. Resulta pues, que podemos relacionar esta figurilla de larario con una Fortuna Tutela.

18 Sobre los orígenes oraculares de la Fortuna romana; Champeaux, J; Op. Cit; Id; Sors Oraculi: les oracles en Italia sous la République et l'Empire; MEFRA 102, 1990; Vázquez Hoys, A. M.; Praeneste y la Fortuna Primigenia. Magia y religión en un culto sincrético; AKROS. Melilla, 2005, pp. 43-48.

Estudios relacionados con Isis; Seco Serra, I; Señora del Destino. La diosa Isis en el mundo grecoromano; Revista de Arqueología N. ${ }^{\circ} 21$ (233). 2000, pp. 44-48; Rubio, R.; Isis. Nuevas perspectivas; Madrid, 1996; Turcan, R.; Los cultos orientales en el mundo romano; Madrid, 2001; Alvar, J.; Los misterios. Religiones «orientales» en el Imperio Romano; Barcelona, 2001.

19 Numerosos estudios sobre el simbolismo de la serpiente dentro de la religión y el poder nos los ofrece la Prof. Vázquez Hoys, entre los que destacamos: Cultos y ritos de fecundidad y su simbología: las aguas en la Hispania romana; Madrid, 1981, pp. 167-184; Aproximación a la magia, la brujería y la superstición en la antigüedad; Madrid, 1989; Isis-Osiris en forma de serpiente; Homenaje a F. Presedo; Sevilla, 1991, pp. 99-119. 
Tenemos, dentro de las fuentes escritas, información relativa al rito de iniciación del culto mistérico de Isis. Apuleyo, en sus Metamorfosis o Asno de Oro (Libro $\mathrm{XI}, 23)$, habla por boca de su protagonista Lucio y nos relata como éste se inicia en el culto de la diosa. Pero en su obra se confunden ambas divinidades, Isis e IsisFortuna, y no llegamos a tener claro si el protagonista se pone al servicio de una o de otra. Esta iniciación se lleva a cabo mediante ritos de purificación por inmersiones y aspersiones de agua, seguidas de un riguroso ayuno. Posteriormente Lucio entrará al servio de la divinidad, ritos secretos que no se puede relatar. Y es que el agua es un agente protector contra encantamientos, símbolo de la renovación de la vida, germen creador y forma parte de la iniciación de los ritos mistéricos. El bautismo o inmersión en agua representa regresar a ese estado de preexistencia, implica la muerte y la resurrección, pero dentro de una vida nueva, purificada. Este baño otorga una vida nueva, con nuevas fuerzas y vitalidad renovada y superior. Esta nueva fortaleza es espiritual, ya que el neófito ha podido vencer a la muerte y renace con vida nueva, abriendo una puerta hacia la inmortali$\operatorname{dad}^{20}$.

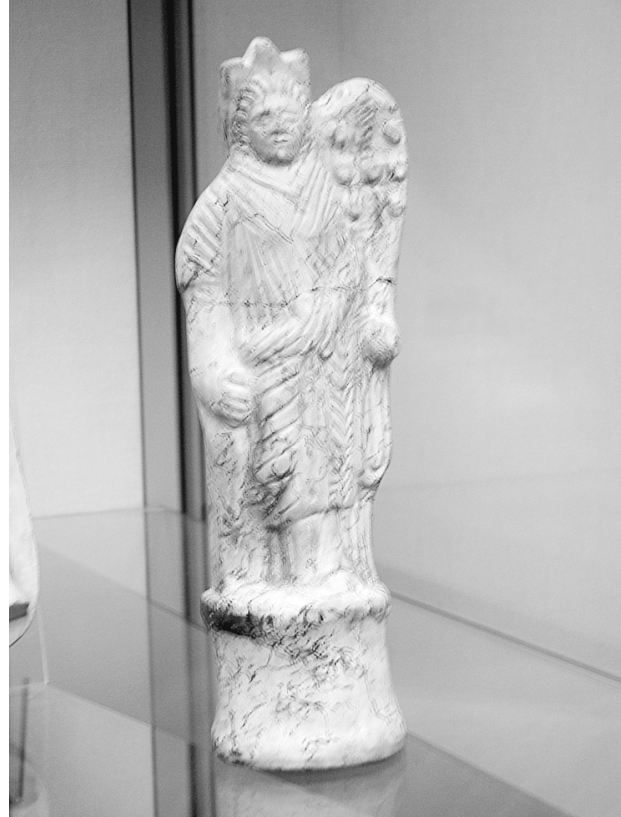

Fig.01. Terracota Fortuna Colonia.

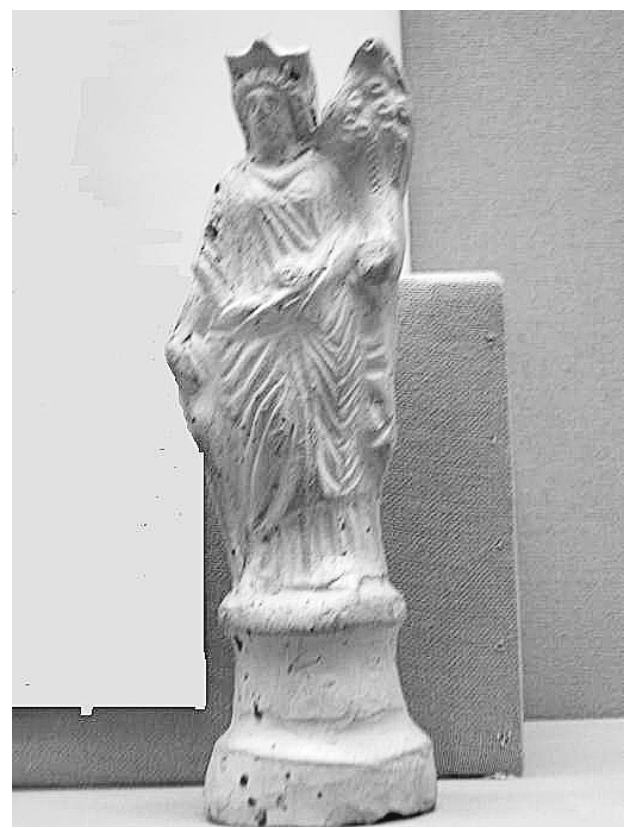

Fig.02. Terracota Fortuna Frankurt.

20 Numerosos trabajos podemos encontrar sobre estudios que relacionan el elemento acuático con usos o creencias y sincretismos religiosos. Entre ellos podemos destacar: Eliade, M.; Imágenes y Símbolos; Madrid, 1999, pp. 165-172; Cumont, F.; Op. Cit., p. 44, Alvar, J,; Op. Cit. Diez de Velasco, F.; Balnearios y divinidades de las aguas termales en la Península Ibérica en época romana; Microficha. Madrid, 1987; Id.; Termalismo y Religión. La sacralización del agua termal en la Península Ibérica y el norte de África en el mundo antiguo; Madrid, 1998; Casado Quintanilla, B. (dir.); Termalismo; Espacio, Tiempo y Forma. Serie II. N. ${ }^{5}$. Historia Antigua; UNED. Madrid, 1992. 


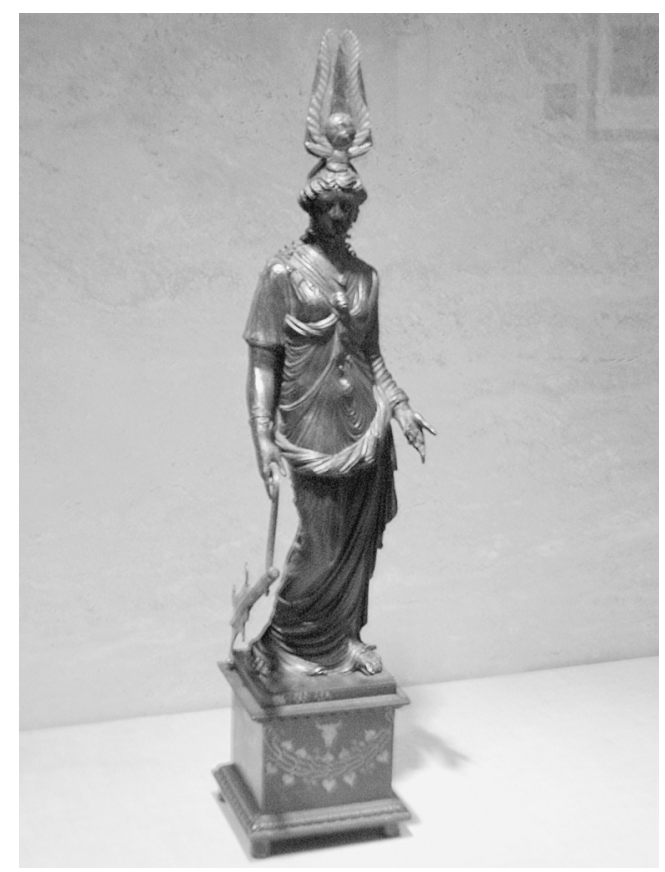

Fig.03. Bronce Isis-Fortuna Herculano.

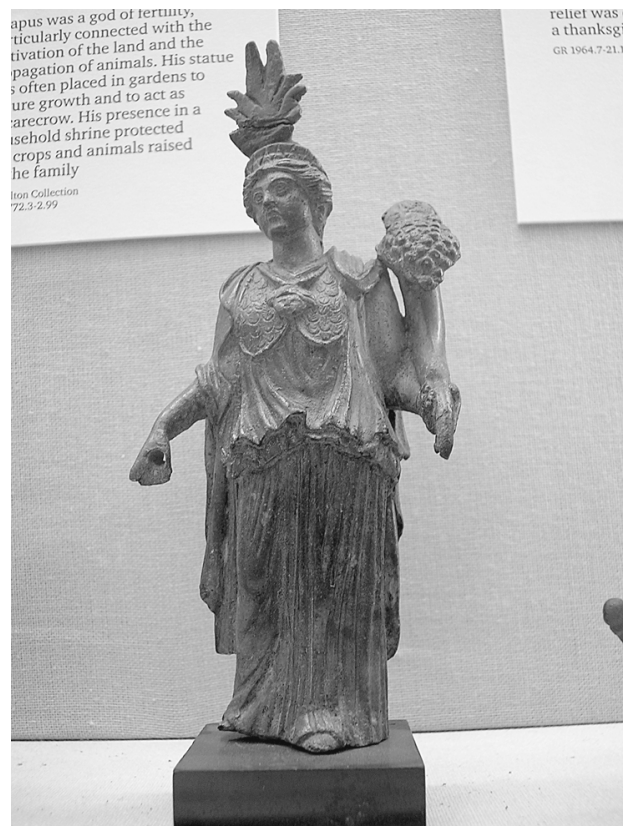

Fig.04. Bronce Minerva-Isis-Fortuna Roma.

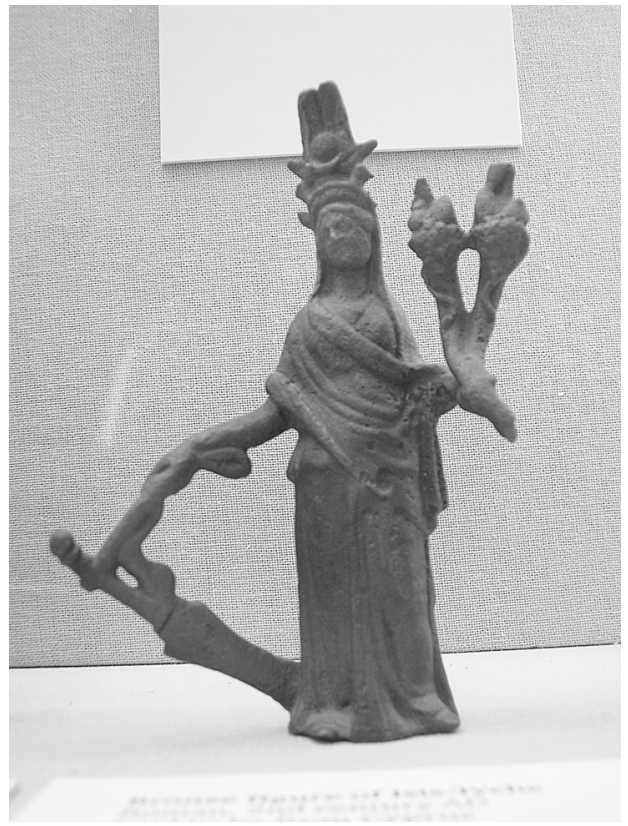

Fig.05. Bronce Isis-Fortuna Roma.

(C) UNED. Espacio, Tiempo y Forma Serie II, Historia Antigua, t. 19-20, 2006-2007 
Durante la crisis de pensamiento y pérdida de fe en los dioses tradicionales que sufre el Imperio romano durante los siglos II y III d.C. y ante la búsqueda de respuestas filosófico-religiosas ante la vida y existencia, cambia el sentido de lo que es fundamental y la religiosidad se transforma. Fortuna se constituirá en una protección supersticiosa y mágica. Esta protección mágica formará parte también del culto individual y quedará plasmada a través de exvotos o pequeñas figurillas protectoras como muestran las imágenes que mostramos a continuación (Fig. 05, $06,07)$, que muy bien pudieran estar ligadas al culto doméstico como figuras de larario.

Por encima de los dioses había una fuerza superior, un dominio al que no podían escapar, ésta era el Destino o la Fortuna. Así pues, el fatum romano u orden preestablecido que garantizaba Júpiter, y que gobernaba tanto a dioses como a hombres, debía someterse en numerosas ocasiones al capricho de la Señora del Destino o Fortuna que derogaba esas leyes que imprimen la razón o fatum, y participaba de aspectos mágicos y supersticiosos ${ }^{21}$. Dión de Prusa dentro de sus Discursos, tres de ellos dedicados a Fortuna, nos hace partícipes de esta idea ligando a Fortuna con la Fuerza Suprema a la que se le atribuyen los éxitos y fracasos de la vida del ser humano.

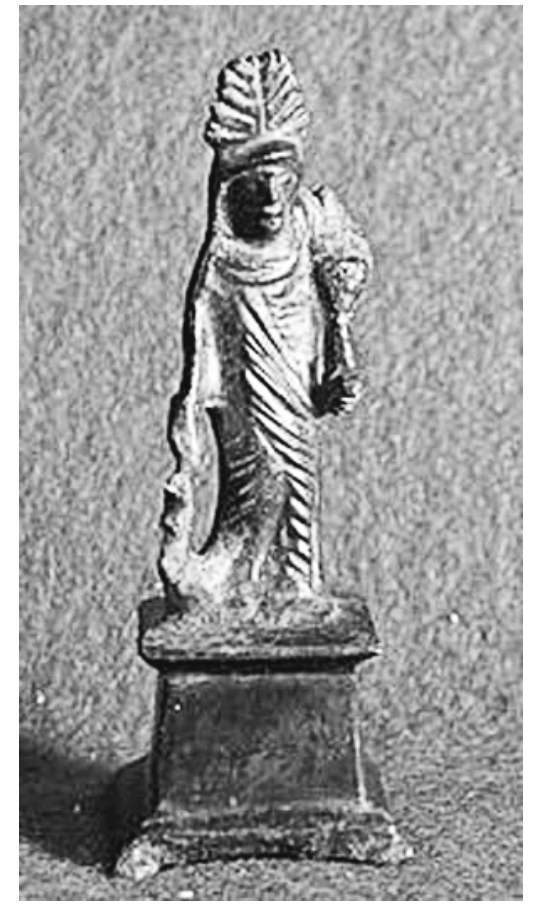

Fig.06. Bronce Isis-Fortuna.

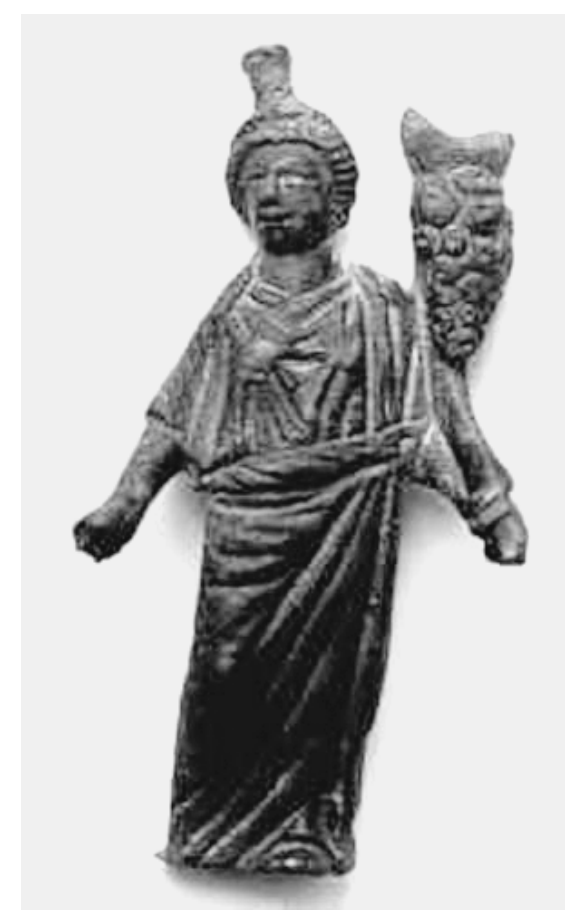

Fig.07. Bronce Isis-Fortuna Bosnia. Dalmacia.

${ }^{21}$ Seco Serra, I; Op. Cit., p. 44. Montero Herrero, S; Diosas y adivinas..., p. 31. 


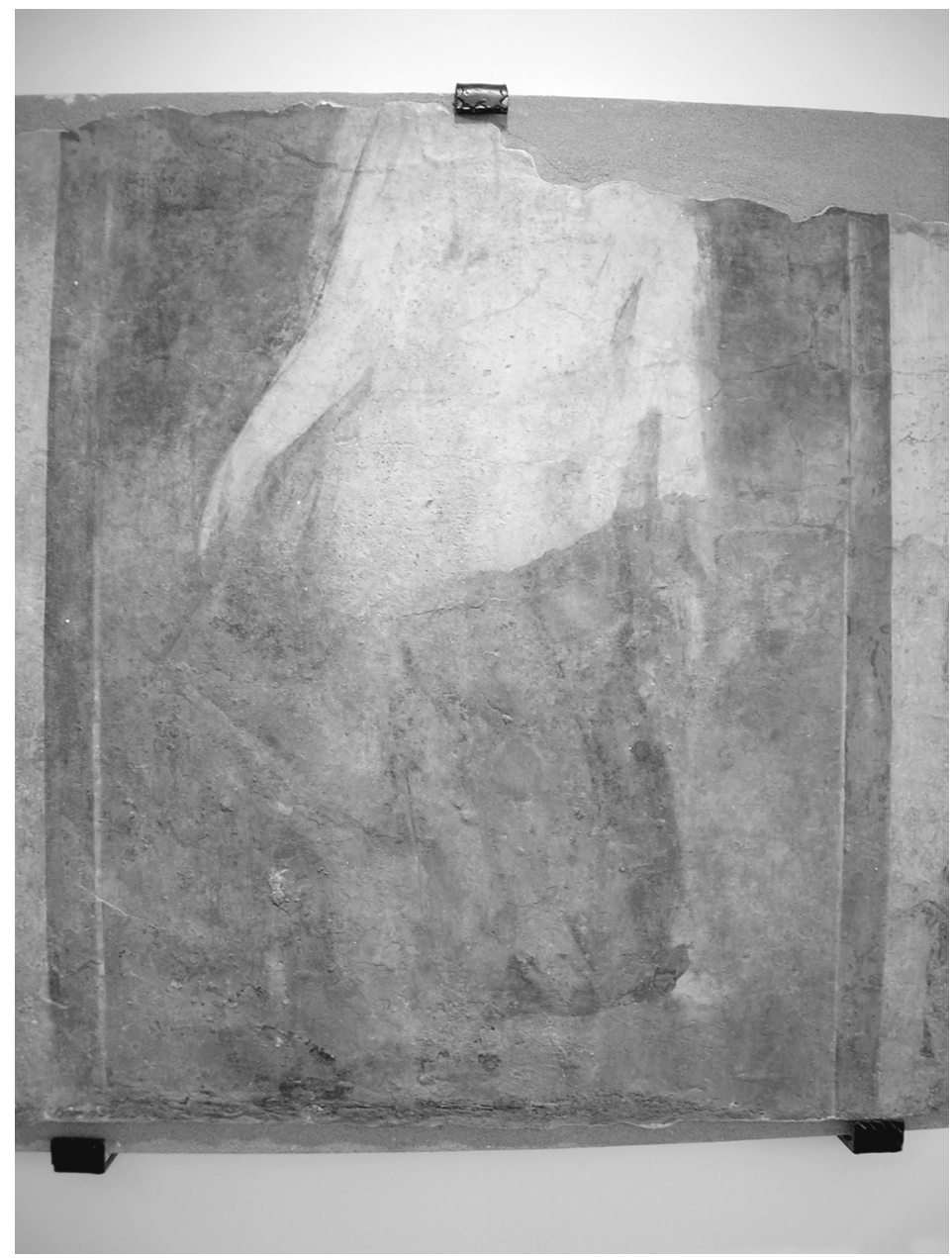

Fig.08. Fresco Fortuna Bilbilis (Caesaraugusta).

Este momento resulta ser el de mayor auge y popularización de nuestra divinidad por todo el territorio imperial. Fortuna se constituye como la gran protectora de las «clases medias", de pobres y esclavos, pero también de las clases aristocráticas, y es reproducida en todos los objetos cotidianos, en vajillas, estatuillas de culto o exvotos. Fortuna representaba para estos sectores más desfavorecidos de la población una oportunidad para mejorar socialmente y esperar «el golpe de suerte». El genio o fuerza del que es promotor la deidad guarda una protección a corto plazo que hace al dedicante portador de una posible felicidad inmediata. A través de pequeños exvotos o figurillas de culto, junto con aras votivas, el propietario busca un beneficio y el éxito de las acciones emprendidas a corto plazo.

La vanalización y popularización de la diosa Fortuna, en la búsqueda del fetiche que proporcione el éxito rápido y fácil, hace que proliferen pequeñas estatuillas 


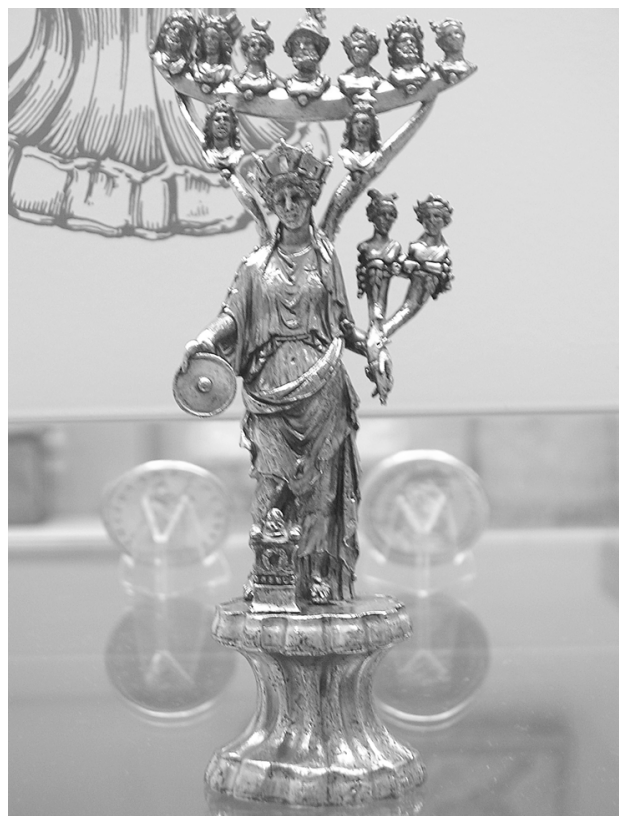

Fig.09. Plata-Oro Fortuna-Tutela Roma.

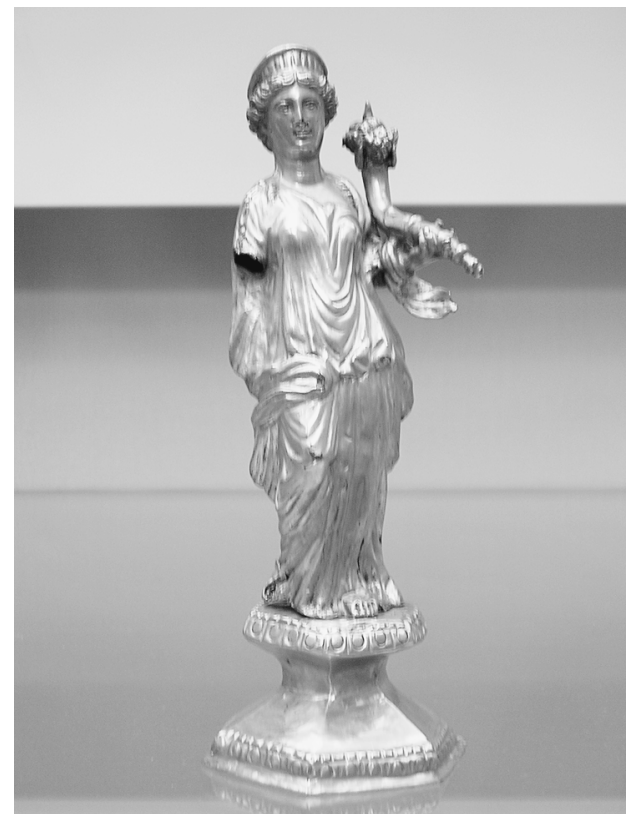

Fig. 10. Plata-Oro Fortuna Gaul.

de la diosa. Estas representaciones, como más arriba hemos apuntado, pueden ligarse al culto de larario o del hogar, aunque hay otro tipo de representaciones que apuntan no al culto sino a ser simplemente objetos de decoración. Ahora nos referiremos a algunos objetos elaborados en materiales nobles, como oro y plata, que tendrían como propietarios los sectores de población más opulentos.

Mostramos a continuación dos figurillas (Fig. 09, 10) elaboradas en materiales nobles, oro-plata, que sirven como ornamento. Ambas tienen una factura muy cuidada y depurada, lo cual nos permite decir que la diosa también tuvo gran aceptación entre la población aristocrática, puesto que el consumo de estos objetos sería efectuado por este grupo social.

Destacar la Fig. 09, en cuanto a que se trata de una Fortuna-Tyché, genio tutelar de la ciudad. Las ciudades representan el lugar donde se expresaba de mejor manera la civilización romana, y donde los diferentes grupos sociales se relacionaban de distinta forma. Pero ante todo eran lugares donde se representaban las elites y donde se construía la formación ideológica de los diferentes grupos sin parámetros igualitarios.

Podemos destacar otro ejemplo de popularización y expansión de la diosa Fortuna-Tutela a lo largo del Imperio, en esta ocasión se trata de la pátera de plata dorada procedente de la Colección Calzadilla de Badajoz, en la provincia lusitana. Aquí es una divinidad local lusitana la que se ha fundido con otras del panteón greco-romano. Esta pieza tiene una inscripción dedicada a la divinidad local 
Band(uae) Araugel(ensi). La figura de una diosa se sitúa en el centro del medallón. Rodeada de un arbusto, unos peñascos y cuatro aras, tres de ellas encendidas. La diosa sostiene en su mano izquierda el Cuerno de Amaltea y en su derecha una pátera. Una corona mural cubre su cabeza. Esta representación nos muestra una Fortuna Tutela, protectora de las ciudades, la familia o la gens. La asimilación de esta divinidad local lusitana, cuyo radical comienza por Band-, con Fortuna Tutela explica la aparición de divinidades similares en Hispania, como muchas Tutelae ligadas a otras divinidades locales ${ }^{22}$.

También elaborada en material noble tenemos la pátera del Tesoro de Pietroasele, que se encuentra actualmente en el Museo de Historia de Bucarest (Rumanía). En ella se representan numerosas divinidades situadas en círculo, en cuyo interior se sitúa la figura central de una diosa sedente sobre un carro cuyos atributos hacen pensar que se trataría de Cibeles. De entre las divinidades que rodean a Cibeles se encuentra Fortuna acompañada del Cuerno de la Abundancia. Es de una factura que cuida infinitamente numerosos detalles.

El nuevo carácter adquirido por Fortuna hace que se fabriquen numerosos artículos no sólo con finalidad religiosa, sino que en numerosas ocasiones eran adquiridos como objetos decorativos, como ya hemos apuntado, o para uso cotidiano. Para este último fin podemos encontrar cerámicas de lujo o cerámicas comunes, para uso cotidiano de factura más deficiente. Podemos poner como ejemplo a Hispania para hacer un repaso de la importancia de la fábrica y factura de los distintos talleres, y extrapolar este ejemplo a cualquier provincia del Imperio. Durante el siglo I d.C. se instalan los primeros talleres, destacando por su decoración figurada los de Bezares, Tricio, Andujar y Mérida. Los dioses que aparecen con mayor asiduidad entre las representaciones son Victoria, Cupido, Fortuna, Mercurio y Venus. Sin duda, la factura de las representaciones dependería de la calidad de acabado de cada taller. Lo que sí parece destacable, por las representaciones halladas, es el gusto del cliente a la hora de adquirir unas cosas u otras. Evidentemente, la preferencia de unas imágenes religiosas, como es el caso de Victoria o Fortuna, respecto a otras, denota un acogimiento positivo de este tipo de representaciones por parte de los clientes.

La clientela hispana que adquiría este tipo de objetos estaba profundamente romanizada y en las representaciones de las diferentes deidades no encontramos ningún atributo de dioses indígenas, ni ningún signo de interpretación local. Por

22 Respecto a los sincretismos de Fortuna Tutela con divinidades indígenas hispanas; Blázquez, J.M.; El sincretismo en la Hispania romana entre las religiones indígenas, griega, romana, fenicia y mistéricas; en VV.AA.; La Religión Romana en Hispania; CSIC. Madrid, 1981, pp. 188. 201. Blázquez, J.M.; Diccionario de las Religiones Prerromanas de Hispania; Madrid, 1975, pp. 43-44. 177; Id.; Imagen y Mito. Estudios sobre las religiones mediterráneas e ibéricas; Madrid, 1977; Id.; Religiones, ritos y creencias funerarias de la Hispania prerromana; Madrid, 2001; Id.; Los cultos sincréticos y su propagación por las ciudades hispanorromanas; Madrid, 2001 (versión digital); Marco Simón, F.; Historia de las religiones de la Europa Antigua; Madrid, 1994, pp. 341-342; Pozo, S.F.; La vajilla metálica de la provincia Baetica. III. La argentería romana; ANTIQVITAS N. ${ }^{17}$. Córdoba, 2005, pp. 41, 51, 56. Otros estudios sobre objetos de plata dentro del Imperio romano: Baratte, F.; Musée du Louvre. L'argenterie romaine; París, 1976. 
otra parte se trataría de clientes poco cultivados, posiblemente de ámbito urbano y de limitados recursos económicos.

El significado de Fortuna, Victoria o Mercurio, en este tipo de piezas podría tratarse de la personificación de una energía o una felicidad inmediata, recogiendo el aspecto más funcional de la vida diaria de cada persona. Estas representaciones guardan relación con la adquisición de un amuleto, fetiche, que sirve para lograr un triunfo inmediato o la protección a corto plazo, no se trata de un culto a los dioses propiamente dicho ${ }^{23}$.

La Fig. 11 muestra una lucerna de uso común hallada en Mérida y expuesta en el Museo de Arte Romano. Muestra la imagen de la diosa Fortuna llevando el timón en su mano derecha que dirige los destinos humanos y del Cuerno de la Abundancia en su izquierda que proporciona a los hombres felicidad, prosperidad, triunfos y protección ante cualquier adversidad. Parece que la elaboración y la factura es de realización local. Lámparas con este mismo motivo podemos encontrarlas también a lo largo de la provincias Lusitana, Bética y Tarraconense.

Lo mismo podríamos decir de los fragmentos de lucernas (Fig. 12 y13) encontradas en Cartagena, situadas en el Museo Arqueológico de la misma ciudad. En el primer caso nos encontramos ante dos representaciones enfrentadas.

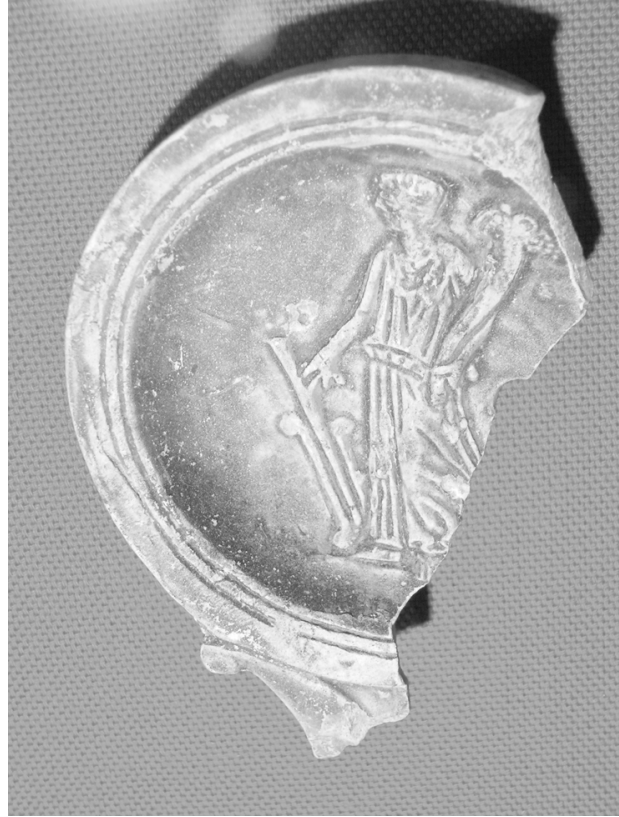

Fig.11. Lucerna Fortuna Mérida M.A.R.

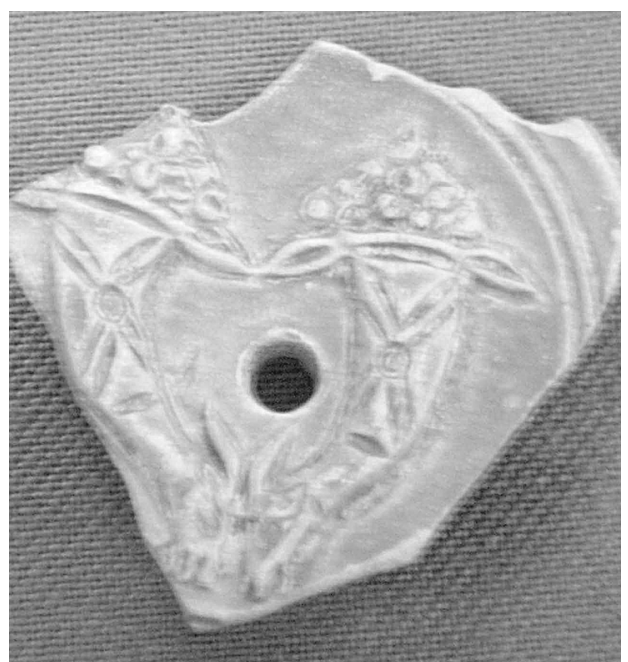

Fig. 12. Lucerna Cornucopias y Amaltea Cartagena.

${ }^{23}$ Elvira Barba, M.A.; Los dioses romanos en la Terra Sigillata hispánica; en VV.AA.; La Religión Romana en Hispania; CSIC. Madrid, 1981, p. 61-66; Vázquez Hoys, A.M.; Aproximación a la magia... 


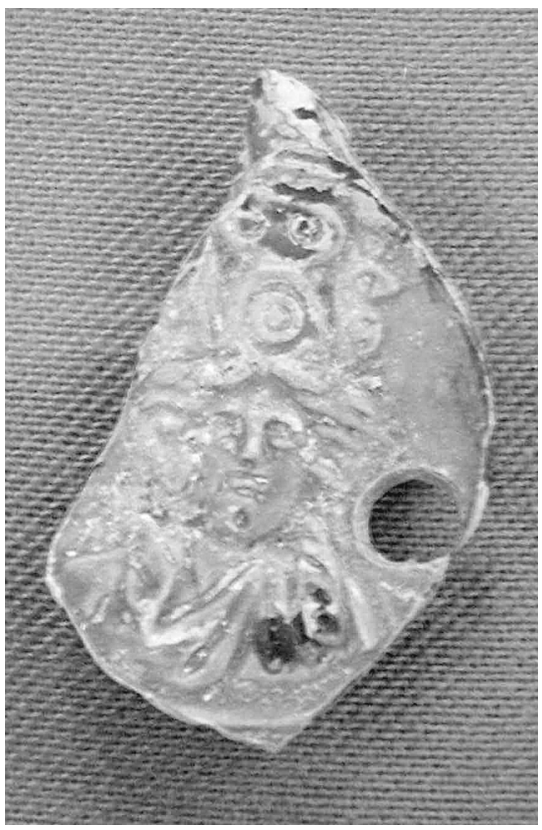

Fig. 13. Lucerna Isis-Fortuna Catagena.

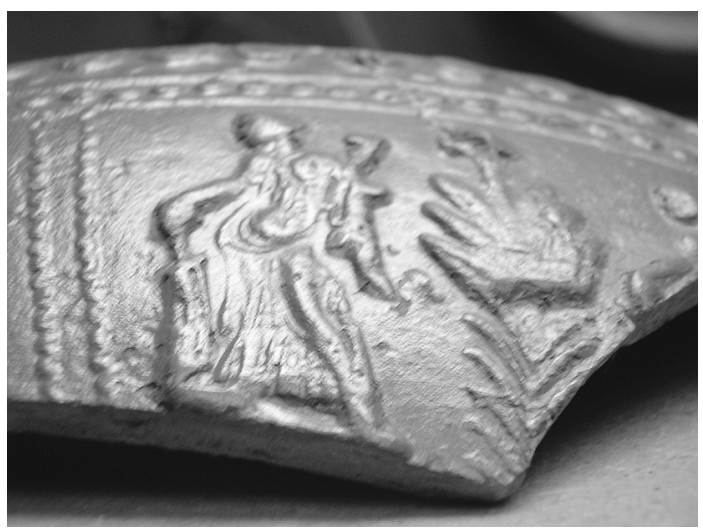

Fig. 14. Terra Sigillata Fortuna La Rioja. Museo Provincial Zaragoza.

En la parte inferior del disco figura de la cabra Amaltea, de cuyo cuerno sale un gran cuerno de la abundancia. Esta escena es repetida de forma simétrica. El diseño de la decoración de esta lucerna requiere por parte del taller cierta inquietud cultural. Este tipo de motivo no es muy repetido aunque encontramos otro ejemplo, esta vez se trata de una lucerna completa, en la ciudad de Córdoba, que se encuentra en el Museo Arqueológico de la misma ciudad ${ }^{24}$.

En el caso de la Fig. 14 nos encontramos ante un fragmento de vaso de Terra Sigillata con decoración realizada a molde, procedente de La Rioja y que actualmente se encuentra en el Museo Provincial de Zaragoza. Se halla recubierta en su parte exterior por un engobe rojizo. Este tipo de cerámica de lujo, de gran difusión a partir del siglo I, era muy apreciada. En este caso, y debido a su factura depurada, podemos deducir que su uso llegaría a capas altas de la sociedad. Pero la tendencia de los talleres locales era abaratar los costes de cerámicas, haciendo imitaciones de la Sigillata con decoraciones más toscas, para llegar a sectores más amplios de población ${ }^{25}$.

24 Moreno Jiménez, F.; Las lucernas romanas de la Bética; Tesis Doctoral. UCM 1991. Tomo I.Pág. 598. Tomo II.Pág.949-950.

${ }_{25}$ Paz Peralta, J. A.; Cerámica de mesa romana de los siglos III al vı d.C.; Zaragoza, 1991; Escribano Pardo, J. E. ; Sobre un vaso engobado, con decoración a molde, procedente de Calahorra; Kalakoricos, 4. 1999, pp. 251-256. A través de una pieza hace un estudio de las imitaciones de Terra Sigillata que se realizaron en los talleres locales de Caesar Augusta. 
Otro ejemplo de objetos de uso cotidiano o ritual se conserva en el Museo Arqueológico Nacional de Madrid (Fig. 15). Se trata de una tapa de bronce con la representación de Isis-Fortuna procedente de Pompeya o de Herculano.

Con la misma utilidad que la anterior figura podemos destacar la Fig. 17. Se trata del Arca Ferrata o Aerata, de Turiaso, Tarazona, ubicada en el Museo Provincial de Zaragoza. Este arcón de madera fue recubierto por una placa de bronce y después fueron añadidas diferentes placas, con las representaciones figurativas, en hierro con rellenado en plomo. Este objeto fue encontrado en una piscina que se utilizaba para algún culto relacionado con las aguas. Al mismo tiempo se piensa que su función sería guardar dinero u objetos valiosos, al igual que la tapa anteriormente citada. De las tres representaciones principales, la relativa a Fortuna está situada en la parte central26.

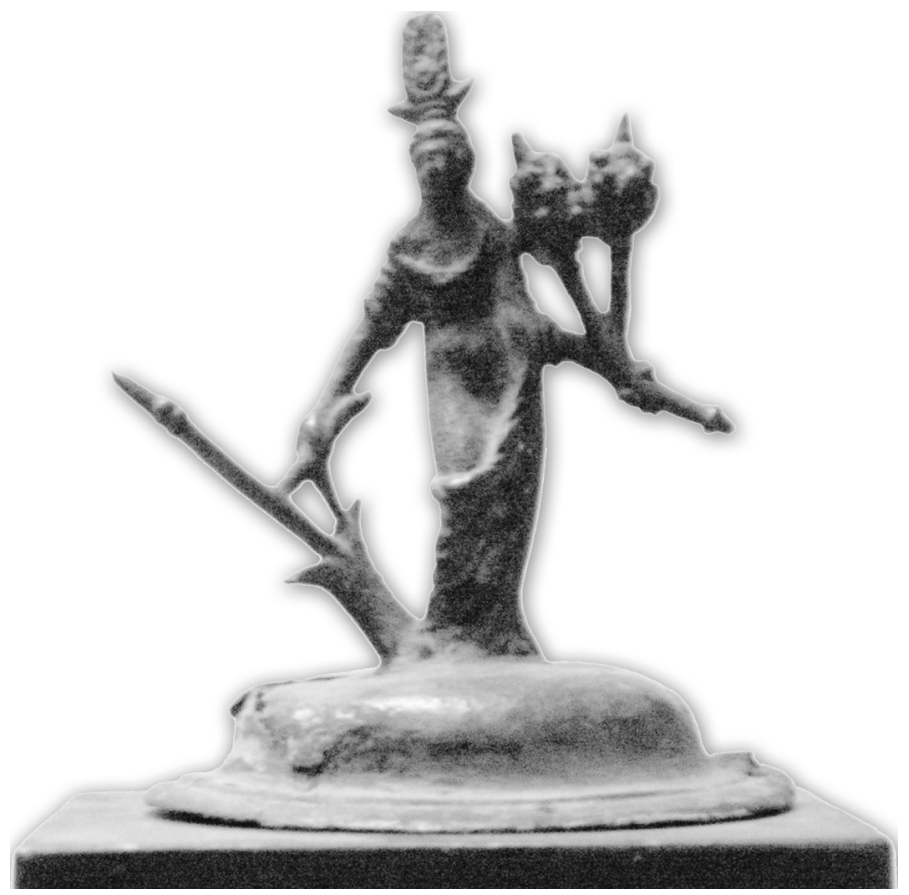

Fig.15. Tapa bronce Fortuna Pompeya o Herculano M.A.N.

26 Beltrán Llois, M. (dir.); Caesaraugusta. Las aguas sagradas del Municipium Turiaso. Excavaciones en el patio del colegio Joaquín Costa (Antiguo Allué Salvador). Tarazona. Zaragoza; Zaragoza, 2004, pp. 143-156, p. 362. El autor considera que la representación de esta figura corresponde únicamente a Abundancia, apuntando que se han encontrado otras representaciones parecidas en otras excavaciones de Pompeya y que en un principio se había valorado la posibilidad de que fuera la diosa Fortuna descartándose finalmente esta filiación. Pero debido a los atributos que expone la diosa (cuerno de la abundancia en su mano izquierda, pátera en la derecha, y diadema), junto con el análisis de piezas halladas similares, podemos considerar que esta identificación puede existir. Además va asociada o acompañada de otras divinidades (en este caso ligadas a los caminos o el poder benéfico del agua), como Mercurio y Apolo, que en numerosas ocasiones acompañan a Fortuna. 


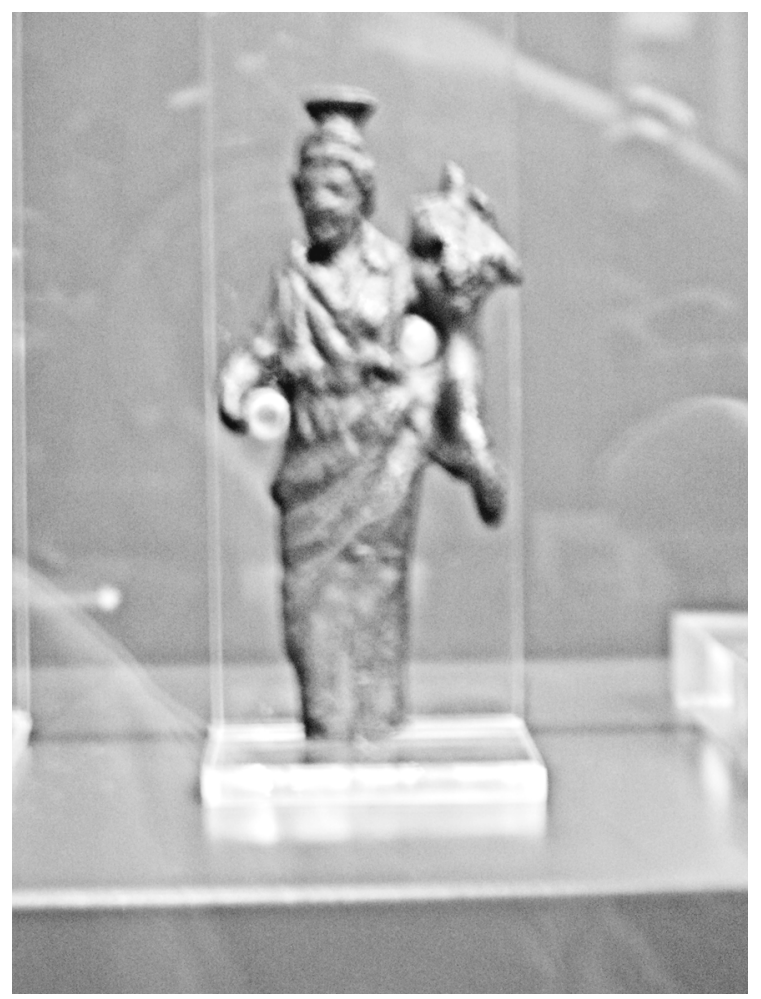

Fig. 16 Posible aplique bronce Fortuna Cartagena. Museo Murcia.

De la pieza expuesta en la Fig. 16, que se encuentra en el Museo Arqueológico de Murcia, procedente de Cartagena, tendríamos que destacar el agujero circular inscrito en su lado izquierdo, entre la cornucopia y su túnica. Al mismo tiempo podemos señalar el descuidado acabado de la parte posterior de la figura. Dicho lo cual, podíamos deducir que se trata, igual que en el caso de las figuras del Arca de Tarazona, de un posible aplique para algún objeto. Figura y objeto quedarían unidos mediante apliques metálicos como en el caso anteriormente estudiado $^{27}$.

La vanalización de la representación de la divinidad, llega a objetos superfluos como los complementos para el vestir. Es decir, se trata de objetos como anillos, camafeos o colgantes. Estos objetos elaborados en materiales nobles, plata y

${ }_{27}$ Noguera Celdrán, J.M., Navarro Suarez, F.J.; Op. Cit., p. 324. Rodá, I.; Bronces romanos de la Hispania Citerior; en Arce, J.(Coord); Bronces Romanos... p. 77. En éste último caso también se identifica a nuestra imagen con Ceres. La representación carece del timón, que posiblemente sujetaría con su mano derecha y se apoyaría en la parte inferior derecha de su túnica, hoy perdido. Por otra parte tendríamos que destacar, con la misma procedencia, una representación de Mercurio que acompaña a Fortuna. Quedarían ligados, igual que en el caso anterior, con las misma finalidad. 


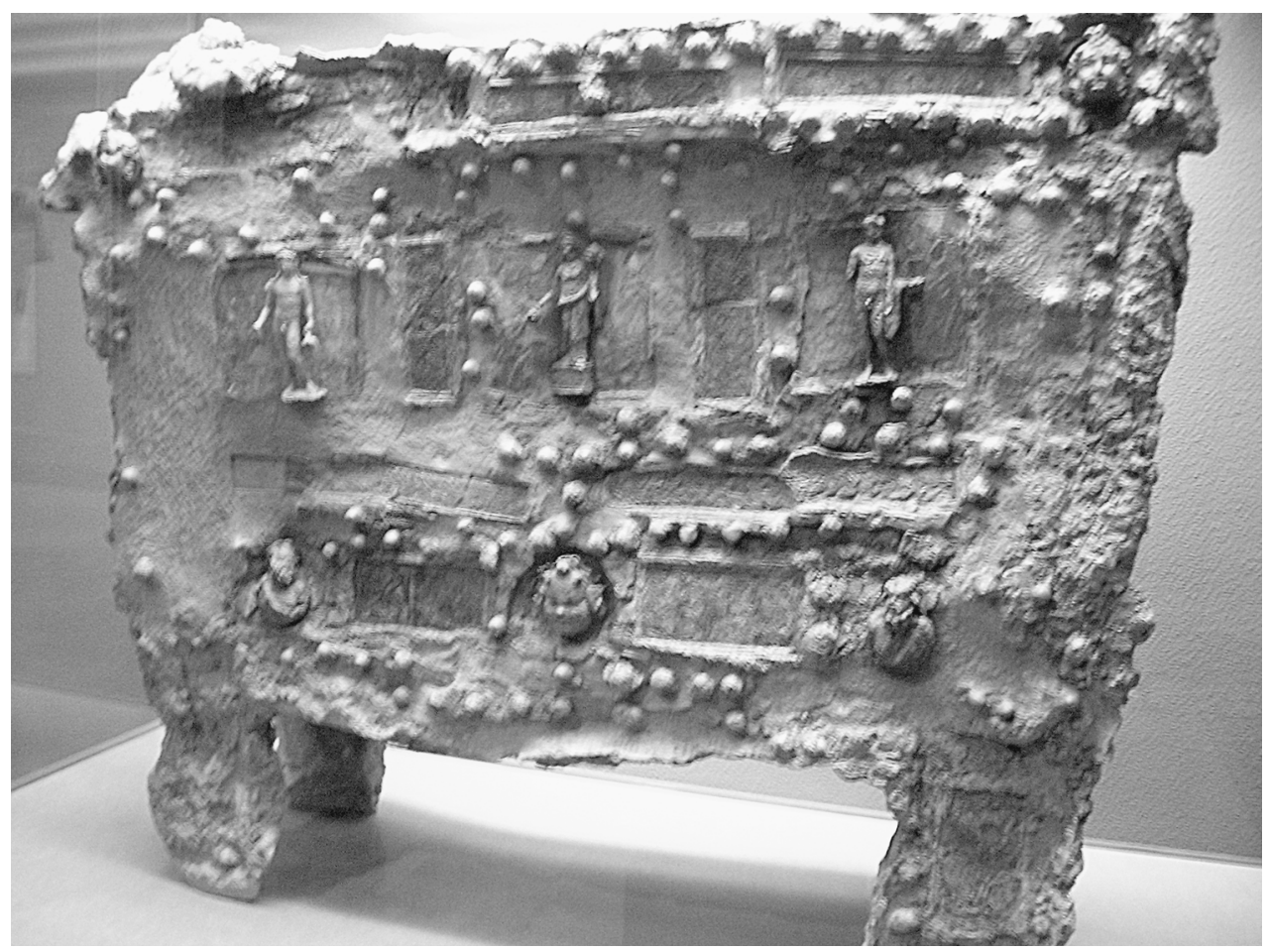

Fig.17 Arca Ferrata Tarazona. Museo Provincial Zaragoza.

oro, llevan la talla de la diosa Fortuna con sus atributos principales, es decir, el cuerno de la Abundancia y el timón. En algunos de ellos, el relieve de la diosa se sitúa en una piedra preciosa (como diamante o gema), la cual va engastada en una pieza de oro.

Como ejemplo podemos poner una de las gemas situadas actualmente en la Cruz de los Ángeles (Oviedo), de principios del siglo IX. De origen romano aunque de procedencia incierta, parece que no es probable su origen hispano, siendo más factible su importación a través del comercio o intercambio medieval de la Península Ibérica con Italia. En impresión negativa, aparece la diosa Fortuna portando en su brazo izquierdo la Cornucopia y en su mano derecha una pátera ${ }^{28}$.

Otro ejemplo de estas representaciones lo encontramos en una pequeña piedra preciosa de tonos anaranjados situada actualmente en el Museo Arqueológico de Alicante. Procede de Tossal de Manises y su datación se encuentra entre los siglos I y II d.C. Esta pieza nos muestra las representaciones de Fortuna (con sus

28 Este ejemplo está documentado en el estudio elaborado por: Perea Yébenes, S.; Demonios en una cruz cristiana. Gemas mitológicas y gnósticas sobre la Cruz de los Ángeles (Oviedo); en Bravo Castañeda, G., González Salinero, R. (eds.), Minorías y sectas en el mundo romano, Madrid, 2006, pp. 211232. 


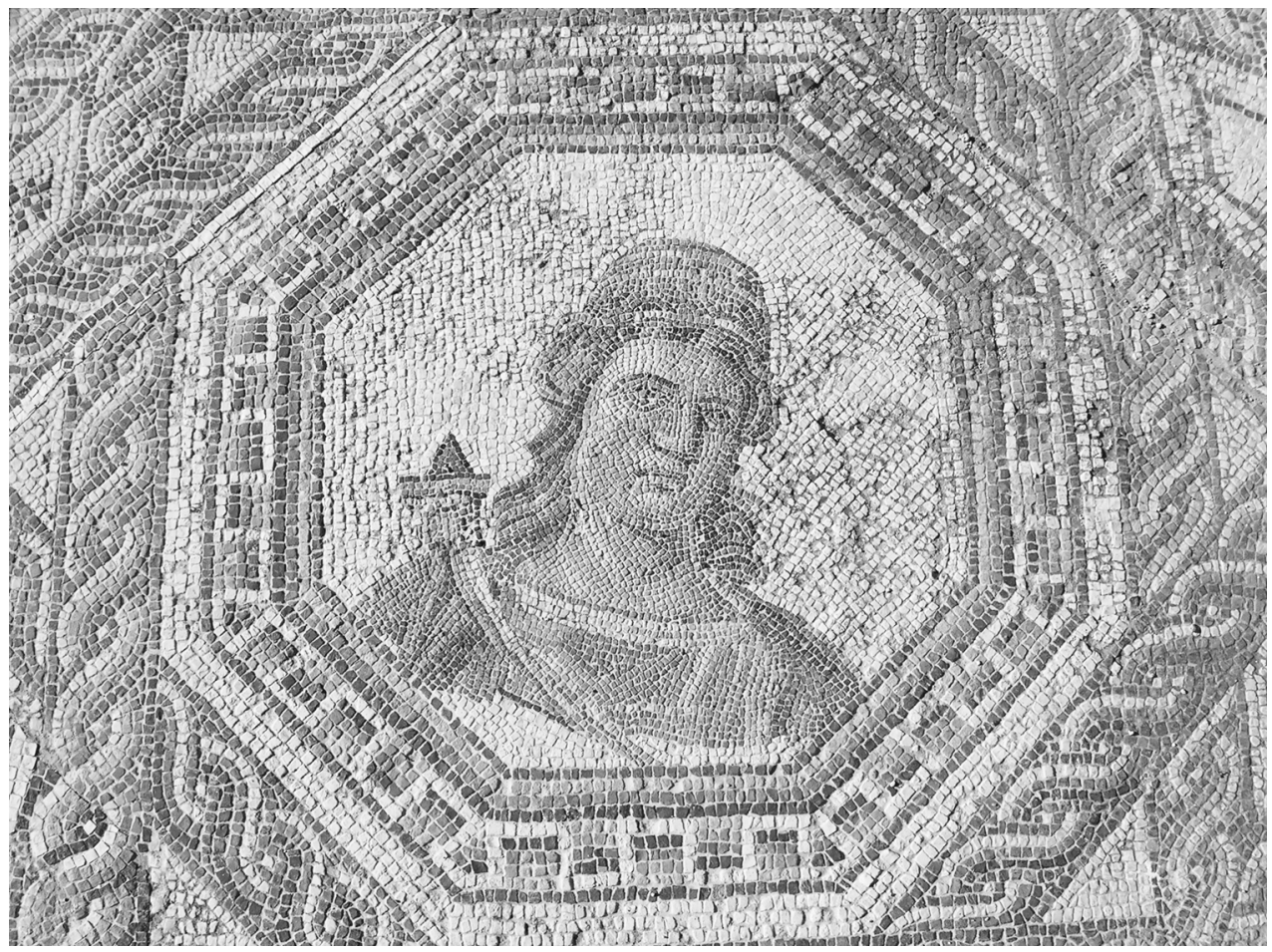

Fig.18. Mosaico. Villa Buñel Quesada (Jaén).

atributos habituales, Cornucopia y Timón) junto al dios Apolo. A simple vista estas representaciones son difícilmente identificables debido a su tamaño. Además de adorno, este tipo de elementos decorativos servían de amuletos o fetiches, que ayudan a su portador. En este caso, Fortuna y Apolo unirán sus fuerzas para favorecer al dueño del amuleto.

Representaciones en ambientes cotidianos también las encontramos en los interiores de las villas romanas. Es el caso de la Fig. 18. Se trata de un mosaico de la Villa Buñel en Quesada (Jaén). De trabajo muy elaborado, en él podemos destacar que la diosa porta una cornucopia y un modius o celemín sobre su cabeza. Se asemeja mucho a las representaciones de la diosa Fortuna aunque también se la puede relacionar con otras divinidades agrícolas, acuáticas o de fecundidad. Diversos estudios han identificado esta representación con la ninfa Tetis, hermana y esposa de Océano, y por lo tanto puesta en relación con la protección de las aguas. Podríamos profundizar algo más en esta cuestión, relacionando el origen, siempre dudoso, de Fortuna con esta representación. Pausanias hace de Fortuna una de las descendientes del dios Océano ${ }^{29}$. Fortuna de esa forma, queda también

29 Pausanias; Descripción de Grecia. Libro IV. 30. 3-6. Bibliografía sobre el mosaico identificado con Tetis en la Villa Buñel. Quesada (Jaen): Del Nido, R.; Edificaciones romanas en el cortijo «Plaza de Ar- 
ligada al mundo acuático, y en ocasiones se la ha considerado también una ninfa protectora. Además como ya hemos visto a lo largo del periodo de crisis religiosa de los siglos II y III d.C. es cuando mayor auge tienen los cultos a las divinidades abstractas como Fortuna.

Resulta un ejemplo destacable, no quedando clara su identificación definitiva, del cual podemos señalar que la representación de las divinidades protectoras se insertaban en todos los ámbitos cotidianos, como es el pavimentado de la domus.

Finalmente podríamos decir que los diferentes cultos a Fortuna, entre ellos los aquí abordados dentro de la Fortuna Privata, tuvieron gran trascendencia para la romanización de las diferentes partes del Imperio. La popularización de ciertos cultos como los de Fortuna, sirvieron para propagar todo el ideario romano a través de todos los territorios y de esta manera, hacer que fuera mayor la dependencia de las provincias hacia la «metrópoli». El culto a Fortuna, a modo de elemento mágico entendido como Azar, perduró a lo largo del tiempo traspasando las fronteras del paganismo y llegando incluso hasta la Edad Moderna, degradándose poco a poco sus funciones protectoras y convirtiéndose en una fuerza caprichosa y arbitraria. Estas formas de veneración, evidentemente, ya no guardaban un componente religioso sino que se decantaban más por sus aspectos mágico-supersticiosos.

\section{FUENTES CLÁSICAS}

APULEYO, RUBIO FERNÁNDEZ, LISARDO (Trad.); Metamorfosis o El Asno de Oro; Ed. Gredos; Madrid, 1995.

CICERÓN, ESCOBAR, A. (Trad.); Sobre la adinivación [Div.; De divinatione]; Ed. Gredos; Madrid, 1999.

CICERÓN, ESCOBAR, A. (Trad.); Sobre la naturaleza de los dioses [Nat.Deor.; De natura deorum]; Ed. Gredos; Madrid, 1999.

CICERÓN, GUILLÉN, J. (Trad.); Sobre las leyes [De Leg.]; Ed. Tecnos; Madrid, 1986.

DIÓN DE PRUSA, DEL CERRO CALDERÓN, G. (Trad.); Discursos; Ed. Gredos; Madrid, 2000.

EL DIGESTO DE JUSTINIANO, D'ORS, A., HERNÁNDEZ-TEJERO, F., FUENTESECA, P., GARCÍA-GARRIDO, M.; BURRILLO, J. (Trad.); Ed. Aranzadi; Pamplona, 1968.

OVIDIO, ÁLVAREZ C., IGLESIAS R.M. (Ed.); Metamorfosis; Ed. Cátedra; Madrid, 2001.

PAUSANIAS, HERRERO INGELMO M.C. (Trad.); Descripción de Grecia. Libros III-X; Ed. Gredos; Madrid, 1994.

PETRONEO, Rubio Fernández, L. (Trad.); El Satiricón; Ed. Gredos; Madrid, 1978.

mas» del Pago de Bruñel (Jaén); Noticiario Arqueológico Hispánico, 8-9, Madrid, 1964-65, pp. $203-209$. Palol, P.; De Sotomayor, M.; Excavaciones en la villa romana de Bruñel (Quesada) de la provincia de Jaén; Actas de los Congresos Internacionales de Arqueología Cristiana (Barcelona, 1969); Roma, 1972. pp. 375-381. Blázquez, J. M.; Corpus de Mosaicos de España; Madrid, 1981. Cap. Mosaicos romanos de Córdoba, Jaén y Málaga. 


\section{BIBLIOGRAFÍA}

ABASCAL PALAZÓN, J.M.; SANZ GAMO, R.; Bronces antiguos del Museo de Albacete; Albacete, 1993.

ALLĖGRE, F.; Étude sur la déesse grecque Tyché. Sa signification religieuse et morale, son culte et ses représentations figurées; París, 1889.

ALVAR, J.; Los misterios. Religiones «orientales» en el Imperio Romano; Barcelona, 2001.

ANDRÉs HuRTADO, G.; Una aproximación a la religión del ejército romano imperial: Hispania; Logroño, 2005.

ARCE, J.; El significado religioso del estandarte romano de Pollentia (Mallorca); en La Religión romana en Hispania, Symposio organizado por el Instituto de Arqueología «Rodrigo Caro» del C.S.I.C., 17-19 de diciembre de 1979, Madrid 1981, p. 75-95.

ARCE, J. (Coord); Los bronces romanos en España; Madrid, 1990.

ARCE, J., Burkhalter, F.; Bronces y religión romana. Actas del XI Congreso Internacional de Bronces Antiguos; Madrid, 1993.

AURRECOECHEA FERNÁNDEZ, J.; La vajilla metálica de época romana en los Museos de Ciudad Real, Jaén y Linares; Espacio, Tiempo y Forma; Serie II, IV. Madrid, 1991, pp. 223-253.

BARATTE, F.; Musée du Louvre. L'argenterie romaine; París, 1976.

BELTRÁN LLOIS, M. (dir.); Caesaraugusta. Las aguas sagradas del Municipium Turiaso. Excavaciones en el patio del colegio Joaquín Costa (Antiguo Allué Salvador). Tarazona. Zaragoza; Zaragoza, 2004.

BLÁZQUEZ MARTÍNEZ, J.M.; Diccionario de las Religiones Prerromanas de Hispania; Madrid, 1975.

BLÁZQUEZ MARTÍNEZ, J.M.a; Imagen y Mito. Estudios sobre las religiones mediterráneas e ibéricas; Madrid, 1977.

BLÁZQUEZ, J. M.; Corpus de Mosaicos de España; Madrid, 1981. Cap. Mosaicos romanos de Córdoba, Jaén y Málaga.

BLÁZQUEZ, J.M. ${ }^{\text {a; }}$ Religiones, ritos y creencias funerarias de la Hispania prerromana; Madrid, 2001.

BLÁZQUEZ MARTÍNEZ, J.M. a; Los cultos sincréticos y su propagación por las ciudades hispanorromanas; Madrid, 2001 (versión digital).

BÁZQUEZ MARTÍNEZ, J.M. a; Los jardines en la Hispania romana; Madrid, 2001 (versión digital).

BOYCE, G.K.; Corpus of the Lararia of Pompeii; MAAR, XIV. 1937

CABRERO, J.; Breve síntesis bibliográfica sobre el ejército romano; ETF(2), 16, (2003), pp. 233-278.

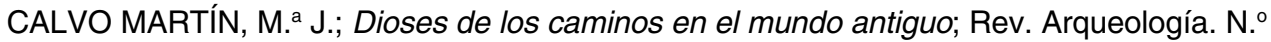
220, pp. 20-30.

CHAMPEAUX, J; Fortuna. Le culte de la Fortune dans le monde romain. II Les transformations de Fortuna sous la République; Roma, 1987.

CHAMPEAUX, J; Fortuna: Recherches sur le culte de la Fortune à Rome et dans le monde romain des origins à la mort de César. I Fortuna dans la religión archaïque; Roma, 1982.

CHAMPEAUX, J; Sors Oraculi: les oracles en Italia sous la République et l'Empire; MEFRA $102,1990$.

CASADO QUINTANILLA, B. (dir.); Termalismo; Espacio, Tiempo y Forma. Serie II. N. ${ }^{5}$. Historia Antigua; UNED. Madrid, 1992.

CUMONT, Franz; Las religiones orientales y el paganismo romano; Madrid, 1987. (Conferencias pronunciadas en 1905).

DAREMBERG, Ch; Saglio, EDM; Dictionnaire des antiquités Grecques et Romaines; Graz, Austria, 1963. 
Aspectos de la «Fortuna Privata»: Culto individual y doméstico. Popularización...

DEL CERRO CALDERÓN, G.; Reflexiones sobre la diosa Tykhe / Fortuna; Analecta Malacitana; 27. N. ${ }^{\circ}$ 1; Málaga, 2004, pp. 143-154.

DEL NIDO, R.; Edificaciones romanas en el cortijo «Plaza de Armas» del Pago de Bruñel (Jaén); Noticiario Arqueológico Hispánico, 8-9, Madrid, 1964-65, pp. 203-209.

DIEZ DE VELASCO, F.; Balnearios y divinidades de las aguas termales en la Península Ibérica en época romana; Microficha. Madrid, 1987.

DIEZ DE VELASCO, F.; Termalismo y Religión. La sacralización del agua termal en la Península Ibérica y el norte de África en el mundo antiguo; Madrid, 1998.

DWYER, E.J.; Pompeian Domestic Sculture. A study of five pompeian Hauses and their contexts; Roma, 1982.

ELIADE, M.; Imágenes y Símbolos; Madrid, 1999.

ELVIRA BARBA, M.A.; Los dioses romanos en la Terra Sigillata hispánica; en VV.AA.; La Religión Romana en Hispania; CSIC. Madrid, 1981.

ELVIRA BARBA, M.A.; Schröder, S.; Bajo el signo de Fortuna. esculturas clásicas del Museo del Prado; Salamanca, 1999.

ESCRIBANO PARDO, J. E. ; Sobre un vaso engobado, con decoración a molde, procedente de Calahorra; Kalakoricos, 4. 1999, pp. 251-256.

ÉTIENNE, R.; Le culte imperial dans la Péninsule Ibérique d'Auguste á Dioclétien; París, 1974.

FERNÁNDEZ PALACIOS, Fernando y UNZUETA PORTILLA, Miguel; Sobre la Isis-Fortuna de Peña Forua (Forua, Vizcaya) y el Mercurio de la Polera (Ubierna, Burgos): Una introcucción al reconocimiento de figuras de Larario; Veleia. Revista de Prehistoria, Historia Antigua, Arqueología y Filología Clásicas. 1998. Pp 145-155.

FERNÁNDEZ URIEL, P; Historia de Roma. V. II; Madrid, 2001.

FERNÁNDEZ URIEL, P.; ESPINOSA, T.; Lararios y culto privado. Algunos aspectos; en Actas de Congreso Internacional El mundo religioso hispano bajo el Imperio romano. Pervivencias y cambios; Valladolid, 19-21 Octubre 2006.

GALINSKY, K. (Dir.); The goddes Fortuna in Imperial Rome: Cult, Art, Text, Texas, 2002.

GARCÍA Y BELLIDO, A.; Esculturas romanas de España y Portugal; Madrid, 1949.

GONZÁLEZ BLANCO, A.; La Cueva Negra de Fortuna (Murcia) y sus Titvli Picti. Un santuario de época romana. Homenaje al Prof. D. Sebastián Mariner Bigorra; Antigüedad y Cristianismo IV; Murcia, 1987.

GONZÁLEZ FERNÁNDEZ, R.; La diosa Fortuna. Relaciones con las aguas y los militares. El caso particular del Balneario de Fortuna (Murcia); en La cultura latina en la Cueva Negra. En agradecimiento a los Profs. A.Stylow, M.Mayer e I.Velázquez; Antig. Crist. XX. Murcia, 2003, pp. 373-386.

GRIMAL, P; Diccionario de mitología griega y romana; Barcelona, 1981.

KAJANTO, I.; Fortuna; ANRW, II. 17.1., 1981, pp. 502-558.

LE ROUX, P.: L'armée romaine et l'organisation des provinces ibériques d'Auguste à l'invasion de 409; París, 1982.

LE ROUX, P. (en prensa): Soldados hispanos en el ejército imperial romano; en Andreu, J., Cabrero, J., y Rodà, I. (eds): Hispania. Provincia Romana; Tarragona, s. pp.

LICHOCKA, B.; L'Iconographie de Fortuna dans l'Empire Romain (1er siécle avant N.Ė. - Ive siècle de N.Ë.); Pologne, 1997.

LOZANO, A.; Antropónimos griegos en la epigrafía religiosa latina. Contribución al estudio sociológico de la religión romana en Hispania; Gerión 7. Madrid, 1989, pp. 207239.

MAIURI, A.; La casa a Pompei; Corso Universitari di antichità Pompeiane dell'anno 1950-51; Nápoli, 1951.

MARCO SIMÓN, F.; Historia de las religiones de la Europa Antigua; Madrid, 1994.

MARTÍN BUENO, M. A.; Elementos de cultos orientalizantes en Bilbilis (Calatayud); Caesaraugusta. N. ${ }^{\circ}$ 39-40. 1975-1976, pp. 165-174.

MEZQUÍRIZ DE CATALÁN, M.A.; Terra Sigillata Hispánica; Valencia, 1961. 
MONTERO HERRERO, S; Diosas y adivinas. Mujer y adivinación en la Roma antigua; Madrid, 1994.

MONTERO HERRERO, S.; Adivinación y esclavitud en la Roma antigua; "llu revista de Ciencias de las religiones; Madrid, 1995, pp. 141-156.

MONTERO HERRERO, S., PEREA YÉBENES, S.; «llu revista de Ciencias de las religiones. Roma Religio/Religio Romanorum. Diccionario Bibliográfico de Religión Romana; Madrid, 1999.

MORENO JIMÉNEZ, F.; Las lucernas romanas de la Bética; Tesis Doctoral. UCM 1991.

NOGUERA CELDRÁN, J. M., NAVARRO SUÁREZ, F. J.; La «Fortuna» del Museo Arqueológico de Murcia: Notas para el estudio de este tipo de estatuillas; en Arce, J., Burkhalter, F. (Coords); Bronces y religión romana; en Actas del XI Congreso Internacional de Bronces Antiguos; Madrid, 1993, pp. 324-330.

ORR, D. G.; Roman domestic religion: The evidence of the household shrines; ANRW II. 1978.

PALAO, J. J.; Legio VII Gemina (Pia) Felix: estudio de una legión romana, Salamanca, 2006.

PALOL, P.; DE SOTOMAYOR, M.; Excavaciones en la villa romana de Bruñel (Quesada) de la provincia de Jaén; Actas de los Congresos Internacionales de Arqueología Cristiana (Barcelona, 1969); Roma, 1972, pp. 375-381.

PAZ PERALTA, J. A.; Cerámica de mesa romana de los siglos III al vı d.C.; Zaragoza, 1991.

PARIS, P.; Le Musée archéologique National de Madrid; Paris, 1936.

PEREA YÉBENES, S.; Demonios en una cruz cristiana. Gemas mitológicas y gnósticas sobre la Cruz de los Ángeles (Oviedo); en Bravo Castañeda, G., González Salinero, R. (eds.), Minorías y sectas en el mundo romano, Madrid, 2006, pp. 211-232.

PEREA YÉBENES, S.; Baños para soldados y el culto a Fortuna; en Pérex Agorrea, M. ${ }^{\mathrm{J}} \mathrm{J}$. (Ed.); Termalismo Antiguo (I Congreso Peninsular. Actas); Madrid, 1997, pp. 149-167.

POMEROY, S.; Diosas, rameras, esposas y esclavas. Mujeres en la Antigüedad clásica; Madrid, 1987.

POZO, S.F.; La vajilla metálica de la provincia Baetica. III. La argentería romana; ANTIQVITAS N.017. Córdoba, 2005, pp. 33-56.

RODÁ, I.; Bronces romanos de la Hispania Citerior. Catálogo de la Exposición «Los Bronces Romanos en España»; Madrid, 1990, pp. 71-90.

RODRÍGUEZ ALONSO, C; Tyche y Areté en el proceso histórico de Roma según Plutarco; García Valdés, M. (Ed.); Estudios sobre Plutarco: ideas religiosas. Actas del III simposio internacional sobre Plutarco, Oviedo 30 abril a 2 mayo de 1992; Ed. Clásicas. Madrid, 1994, pp. 447-454.

RODRÍGUEZ GARCÍA, P.; Cultos domésticos en la Galicia Romana; Congreso de Arqueología Peninsular. Acta de Congreso; Universidad de Alcalá de Henares, Zamora, 1999.

RODRÍGUEZ OLIVA, P.: Materiales arqueológicos y epigráficos para el estudio de los cultos domésticos en la España romana; Actas VIII Congreso Español de Estudios Clásicos. Vol. III. Madrid, 1994.

ROLDÁN, J.M.; Hispania y el ejército romano. Contribución a la historia social de la España antigua; Salamanca, 1974.

RUBIO, R.; Isis. Nuevas perspectivas; Madrid, 1996.

SECO SERRA, I; Señora del Destino. La diosa Isis en el mundo greco-romano; Revista de Arqueología N. ${ }^{\circ} 21$ (233). 2000, pp. 42-49.

THOUVENOT, R.; Catalogue des figurines et objets de Bronze au Musée archéologique de Madrid. I. Bronzes greecs et romains; Bheh, Fasc. XII, 1. Bourdeauz, París, 1927.

TURCAN, R.; Los cultos orientales en el mundo romano; Madrid, 2001.

TURCAN, R.; Iconography of religions. Section XVII, 1. Religion romaine. Part 1, 2; The Netherlands, 1988. 
VÁZQUEZ HOYS, A.M.; La Religión Romana en Hispania. Fuentes epigráficas, arqueológicas y numismáticas; Madrid, 1982.

VÁZQUEZ HOYS, A. M.; Praeneste y la Fortuna Primigenia. Magia y religión en un culto sincrético; AKROS. Melilla, 2005, pp. 43-48.

VÁZQUEZ HOYS, A.M.; Cultos y ritos de fecundidad y su simbología: las aguas en la Hispania romana; Madrid, 1981, pp. 167-184.

VÁZQUEZ HOYS, A.M.; Aproximación a la magia, la brujería y la superstición en la antigüedad; Madrid, 1989.

VÁZQUEZ HOYS, A.M.; Isis-Osiris en forma de serpiente; Homenaje a F. Presedo; Sevilla, 1991, pp. 99-119.

VENY, C.; El estandarte romano de «Pollentia» testimonio de la existencia de un «collegium iuvenum»; en Mayurqa, Rev. Departament de Ciències Històriques i Teoria de les Arts. N. ${ }^{\circ}$ 29. Mallorca, 2003, pp. 51-70.

VV.AA.; La Religión Romana en Hispania; CSIC. Madrid, 1981. 